AÜIFD Cilt XLIII (2002) Sayt 2 s. 277-313

\title{
Kurtuluş Savaşı Döneminde ve \\ Cumhuriyet'in Başlarında Türkiye'de Medreseler ve Din Eğitimi
}

\author{
Zeki Salih ZENGİN \\ Doç. Dr., Çukurova Üniversitesi Ilâhiyat Fakültesi \\ e-mail: zsalih@cu.edu.tr
}

Religious Education and Madrasas in Turkey During the Independent War and The Beginning of Republic. Madrasas as a religious association of education had been known that it remained second plan during the modernization of education studies in the Tanzimat period. Afterwards it was planned reformation with regard to Meşrutiyet period. At this article had been examined reorganization of madrasas in the beginning of the Turkish Independent War and Republic era. Medaris-i Ilmiye Nizamnamesi which is prepared at 1921 about the reorganization of madrasas is last studying. It had been comprised curriculums, administration of madrasas and regulars of dicipline. But, academic deficiency and economic disaster by the Turkish Independent War had not to applied it. Consequently, it had been abolished with Tevhid-i Tedrisat that is passed into law at 1924.

Key words: Religious Education, Madrasa

\section{Giriş}

Türk eğitim tarihinin belirli dönüm noktalarından birisinin Tanzimat dönemi olduğu bilinmektedir. Diğer alanlarda olduğu gibi eğitim alanında da 
Batı'nın örnek alındığı bu dönemde geleneksel eğitim kurumlarının yanı sıra modern eğitim kurumlanna da yer verilmiş ve devlet tarafından geliştirilerek yaygınlaştırılmaları asıl hedef olarak benimsenmiştir. Genel eğitim alanındaki bu köklü değişme süreci içinde din eğitiminin yeri konusu müstakil olarak incelenmiştir.' Buna göre Tanzimat yıllarından itibaren ülkemizde iki farklı dünya görüşüne sahip nesiller yetiştirilmeye başlanmış, buna paralel olarak da biri geleneksel eğitim kurumları olan medreselerde, diğeri modern eğitim kurumları olarak açılan mekteplerde amacı, okutulan ders kitaplan ve öğretim usulleri ile temelde birbirinden farklı iki ayrı din eğitimi verilmiştir. Bizim bu makalede amacımız, özellikle Tanzimat'tan itibaren başlayan ve Cumhuriyet'in ilk yıllarına kadar uzanan tarihî seyri içinde son noktayı oluşturan Kurtuluş Savaşı yıllarından Cumhuriyet'in başına kadar $\mathrm{ki}$ dönemde medreselerin düzenlenmesi konusunda gerçekleştirilen çalışmalann sebeplerini, uygulama biçimlerini ve sonuçlarını ortaya koymaktır. Yararlandığımız kaynakların çok önemli bir kısmını, dönem içerisindeki çalışmaların en sağlıklı ve güvenilir biçimde aydınlatılmasını mümkün kılacak niteliğe sahip Cumhuriyet Arşivi’ndeki vesikalar oluşturmaktadır.

\section{A. Medâris-i İlmiye Nizamnamesi ve Din Eğitimi}

Türkiye Büyük Millet Meclisi tarafından hazırlanan ve 26 maddeden oluşan Medâris-i İlmiye Nizamnamesi ile medreselerin idaresi, müderrislerin vazifeleri, talebelerin medreseye kayıt esaslanı ve görevleri ile okutulacak dersler belirlenmektedir. ${ }^{2}$

Nizamnamenin hazırlanı̧̧ gerekçesine (esbâb-1 mûcibe lâyihası) bakıldığında bu hususta öne sürülen başlıca problem Anadolu'nun birçok yerlerinde halka namaz kıldıracak, karşılaştığı dinî problemleri çözebilecek, hatta cenaze kaldıracak yeterli din görevlilerinin bulunmaması olarak ileri sürülmektedir. Son yıllarda seferberlik dolayısıyla medrese talebelerinin de silah altına alınmalarından dolayı medreselerin kapanma noktasına geldiği hususuna dikkat çekilen lâyihada, ihtiyaç duyulan bu görevlilerin

1. Bk. Zeki Salih Zengin, Tanzimat Dönemi Osmanlı Örgün Eğitim Kurumlarında Din Ĕ̈itimi ve Öğretimi (1839-1876), Basılmamış Doktora Tezi, EÜSBE Kayseri 1997.

2. Nizamnamenin metni için, Bk. "Medâris-i Ilmiye Nizamnamesi", 8 Mayıs 1337/30 Şaban 1339 (8 Mayıs 1921), Düstur II, III. Tertib, Milliyet Matbaası, Istanbul 1929, s. 57-61; "Medâris-i llmiye Nizamnamesi", Evkâf-ı İslamiye Matbaası, 1341-1338, s. 611. 
medreselerden yetiştirilecekleri belirtilerek hazırlanan nizamname genel özellikleri ile tanıtılmaktadır. ${ }^{3}$

Medâris-i İlmiye Nizamnamesi'nde dikkati çeken nokta, Ankara hükümetinin kontrolü altındaki yerlerde iki tür medresenin varlığının kabul edilmesidir. Bunlardan ilki Dârü'l-Hilafe medreseleri, diğeri ise Medâris-i İlmiyelerdir. Her iki tür medrese de Şer'iye Vekaleti'ne bağlıdır. Nizamname ile mevcut medreseler iki kısma ayrıldıktan sonra Dâru'l- Hilâfe medreseleri ile İlmiye medreselerinin ilmî teşkilatları ile idare esaslarının da ayn olduğu, Dârü'l-Hilâfe medreselerinin idaresinin başka bir talimata bağlı olup bu nizamnamenin Ilmiye medreseleri için geçerli olduğu ifade edilmektedir. ${ }^{4}$ Medâris-i Ílmiye Nizamnamesi incelenirken, yine burada belirtilen esas gereğince her iki tür medresenin eğitim ve teşkilat yönünden ayrı olarak ele alınması doğru olacaktır.

\section{Dârü'l-Hilâfe Medreseleri}

Araştırmamızda ele alacağımız ilk konu Dârü'l-Hilâfe medreselerinin ilmî̀ ve idarî yapısının düzenlenmesi için hazırlanan talimatnamenin tanıtılması olacaktır. 5 Ancak bu medreselerin inceleyeceğimiz döneme gelmeden önce var oldukları, II. Meşrutiyet döneminde 1914 yılında kuruldukları ve sonraki yıllarda sürekli bir gelişme seyri takip ederek TBMM zamanındaki şekline kavuştukları bilinmektedir. Bu nedenle öncelikle Dârü'l-Hilâfe medreselerinin tarihî gelişimindeki sürekliliği göz ardı etmeden, kuruluş yıllarından itibaren ilmî ve idarî yapısına kısa bir temastan sonra yine bu medreselerle ilgili olarak TBMM zamanında yapılan çalışmaların ortaya konulması amaçlanmaktadır. Böyle bir yaklaşım, belirli bir süreçte oluşan gelişmelerin takibi ve son şeklinin daha iyi tanınması açısından yerinde olacaktır.

Dârü'l-Hilâfe Medresesi, 1914 yılında hazırlanan Islah-ı Medâris Nizamnamesi ${ }^{6}$ ile gündeme getirilen medreseleri ıslah teşebbüsleri sırasında öncelikle Ístanbul medreselerinin yeniden düzenlenmeleri sonucunda

3. "Medâris-i Ilmiye Nizamnamesi Esbâb-ı Mûcibe Lâyihası", Medâris-i Ilmiye Nizamnamesi, Evkâf-ı İslamiye Matbaası, 1341-1338, s. 3-5.

4. "Medâris-i ilmiye Nizamnamesi", mad. 1-2.

5. Bu dönemdeki çalışmalar içerisinde yer alan ders programlarının ve ders içcriklerinin düzenlenmesi çalışmalarının tanıtılması ve tenkidine burada temas etmeycceğiz. Bu konunun ayrı bir çalışmada cle alınmasının daha doğı olacağı düşüncesindcyiz.

6. Nizamnamenin metni için, Bk. "Islâh-ı Medâris Nizamnamesi", 18 Eylül 1330/10 Zilkade 1332 (29 Eylül 1914), Düstur VI, II. Tertib, Matbaa-i Amire, Dersaadet 1334, s. 1325-1330; Ilmiye Salnamesi, Matbaa-i Amire, Istanbul 1334, s. 657-660; Ceride-i tliniye, Islâh-1 Medâris Nứsha-i Fevkaladesi, s. 249-252. 
kurulan medresedir. Yapılan düzenleme ile İstanbul'daki medreselerden öğretime elverişli olanları belirlenerek "Dârü'l-Hilâfeti'l-Aliyye Medresesi" adı ile tek bir medrese olarak kabul edilmiştir.' Klasik medrese yapısından farklı, mevcut diğer yeni tarz öğretim kurumları olan mektepler ömek alınarak çeşitli öğretim aşamalarına ayrılan bu medrese, tâlî kısm-ı evvel ve tâlî kısm-1 sânî (orta öğretim birinci ve ikinci basamaklar) ile âlî (yüksek) olmak üzere üç kısma ayrılarak derecelendirilmiştir. ${ }^{8}$

Dârü'l-Hilafe Medresesi, Islah-l Medâris Nizamnamesi gereğince sonraki yıllarda örnek medrese tipi olarak Anadolu'nun çeşitli vilayetlerinde de açılmıştır. ${ }^{9}$ Taşrada açılan bu medreselerin İstanbul'dakinden öğretim süresi ve derecelerinin yanısıra ders programları bakımından da farklı olduklan görülmektedir. Beş yıllık öğretim süreli bu medreseler orta dereceli ögretim kurumları olarak düzenlenerek programlanında İstanbul'dakinden farklı olarak Farsça, Batı Dilleri ve Beden Eğitimi gibi derslere yer verilmemiş, buna karşılık Usûl-i Terbiye ve Talim (Eğitim ve Öğretim Metodu), İlahi, El İşleri ve Ziraat gibi derslere yer verilmiş̧ir. ${ }^{10}$

İstanbul'daki Dârü'l-Hilâfeti'l-Aliyye Medresesi'nin yanısıra taşrada bulunan medreselerin geliştirilmesi konusuna sonraki yıllarda yapilan çalışmalar içinde de yer verilmiştir. 1917 yılında hazırlanan Medâris-i İlmiye Hakkında Kanun'da"l taşra medreselerinin, İstanbul'da olduğu gibi orta öğretim birinci, ikinci ve yüksek kısımlardan oluşan üç dereceli (derecât-1 sülüse) olarak düzenlenmesi görevinin Meşihat'a ait olduğu belirtilmektedir.12 Yine aynı yıl hazırlanan Dârü'l-Hilâfeti'l-Aliyye

7. "Islâh-ı Medâris Nizamnamesi", mad. 1. 1914 yılındaki medrese islahat çalışmaları için, Bk. Mübahat Kütükoğlu: "Dârü'l Hilâfeti'l Aliyye Medresesi ve Kuruluşu Arefesinde İstanbul Medreseleri", Islam Tetkikleri Enstitiusü Dergisi, Sayı : 7/1-2'den ayrıbasım, Edebiyat Fak. Matbaası, İstanbul 1978; Nesimi Yazıcı: "Osmanlıların Son Döneminde Din Görevlisi Yetiştirme Çabaları Üzerine Bazı Gözlemler", Diyanet Dergisi XXVII, Sayı: 4, Ankara 1991, s. 55-123; Zengin, Zeki Salih: II. Meşrûtiyet Döneminde Medreselerin Islaht Hareketleri ve Din Ĕ̈itimi (19081918), EÜSBE Basılmamış Yüksck Lisans Tezi, Kayseri 1993.

8. "Islâh-ı Medâris Nizamnamesi", mad. 2.

9. "Islâh-t Medâris Nizamnamesi", mad. 18; Ceride-i Illmiye, 2. Scne, Aded 17, Zilkade 1333 (Eylül 1915), s. 216; Ceride-i Mmiye, 3. Sene, Aded 32, Sevval 1335 (Temmuz 1917), s. 915. 1915 yılında Bursa, Edime, Kayseri, Karahisar-ı Sahib, Tire, Ödemiş, Konya, Uşak, Manisa, Amasya, Maraş, Harput, Eskişehir, Kastamonu olmak üzere 14 merkezde Dârü'l Hilafe Medrescsi açılmıştır.

10. Cerîde-i Ilmiye, 2. Sene, Aded 17, (Eylül 1915), s. 216-217; Ilmiye Salnamesi, s. 668.

11. Kanunun metni için, Bk. "Medâris-i Ilmiye Hakkında Kanun", 2 Nisan 1333/10 Cemaziyelâhir 1335 (3 Nisan 1917), Düstur IX, II. Tertib, Evkaf Matbaası, Istanbul 1928, s. 1325-1330; Ceride-i İlmiye, 3. Sene, Aded 31. Cemaziyelevvel 1335 (Şubat 1917), s. 877-880.

"Medâris-i İlmiye Hakkında Kanun", mad. 5. 
Medresesi İle Taşra Medârisi Hakkında Nizamname'de'13 özellikle bu konuya temas edilerek yukarıda sözünü ettiğimiz üç dereceli medreselerin nerelerde açılacakları Meclis-i Mesâlih-i Talebe tarafından yapılacak inceleme sonucuna göre Meşihat tarafından kararlaştırılacağı belirtilmektedir. Medresedeki her bir öğretim derecesi için birer müdür tayin edilecek; ayrıca bu medreselerin açılacağı yerlerde mahallin müftüsünün başkanlığında medrese müdürü, evkaf memuru ve ileri gelen iki müderristen oluşan, medresenin eğitim-öğretim ve idare işlerini düzenlenmesi yanısıra her yıl yapılan tedrisatın neticesini rapor halinde Meşihat'a bildirmekle görevli bir Encümen-i İlmî kurulacaktır. ${ }^{14}$

Dârü'l-Hilâfe Medresesi hakkındaki çalışmaların sonraki yıllarda da devam ettiği, 1922 tarihinde hazırlanan ve bu medreselerdeki yeni program düzenlemeleri hakkında bilgilere yer verilen bir kitaptan anlaşılmaktadır. ${ }^{\text {Is }}$ Dârü'l-Hilâfe Medreseleri'nin taşrada hangi ölçüde yaygınlaştırılabildiği hususunda söz konusu kitapta açık bilgi bulunmamakla birlikte 1921 tarihli Medâris-i Illmiye Nizamnamesi'nin Esbâb-1 Mûcibe Lâyihası'da TBMM Hükümeti'nin kontrolü altındaki bölgelerde 14 Dârü'l-Hilâfe Medresesi'nin olduğundan söz edildiğine bakılırsal6 1915 yılından bu yana Anadolu'da yeni Dârü'l-Hilâfe Medresesi açılmadığı sonucuna varmak mümkündür.

1922 yilında hazırlanan bu kitapta, İstanbul medreselerinin önceki yıllardan beri, bir önceki öğretim yılındaki uygulama sonuçlanna göre yeniden ele alındığı, medresedeki öğretim basamaklarının İhzari (hazırlık), İptidâ-yı Hâriç-Tâlî Kısm-1 Evvel-(orta öğretim birinci basamak), Iptidâ-yı Dâhil-Tâlî Kısm-1 Sânî-(orta öğretim ikinci basamak), Sahn-Kısm-1 Alî(yüksek) ve Süleymaniye-Medresetü'l-Mütehassısîn-(uzmanlık) şeklinde beş basamaktan, her basamağın da üçer sınıftan oluştuğu belirtilerek, Hazırlık kısmına altı yıllık iptidailerin dördüncü sınıfına geçen talebelerin kabul edildiği ifade edilmektedir. Hâriç ve Dâhil medreselerini bitiren talebeler ise daha önce Darülfünun bünyesinde açılan; fakat medreselerin ıslah çalışmalarının başlamasından sonra lağvedilen Ilahiyat Şûbesi derslerini

13. Nizamnamenin metni için, Bk. "Dârü'l-Hilafeti'l-Aliyye Medresesi Ile Taşra Medârisi Hakkında Nizamname" Düstur IX, II. Tertib, 4. Teşrinievvel 1333/16 Zilhicce 1335 (3 Ekim 1917), Evkaf Matbaası, Istanbul 1928, s. 745-752; Takvim-i Vekâyî, No: 3034, 2 Muharrem 1336 / 19 Teşrinievvel 1333 (18 Ekim 1917); Ceride-i llmiye, 3. Sene, Aded 33, Zilhicce 1335 (Eylül 1917), s. 936-943.

14. "Dârü'l-Hilafeti'l-Aliyye Medresesi Ile Taşra Medârisi Hakkında Nizamname", mad. 16-19.

15. Bk. "Dârü'l-Hilafeti'l-Aliyye Medresesi ve Medresetü'l-Kuzât Nizamnamesi", Evkaf-1 İslamiye Matbaas1, 1340-1338, s. 5-9.

16. Krş. "Medâris-i llmiye Nizamnamesi Esbâb-ı Mûcibe Lâyihası", s. 3. 
ihtiva eden Sahn medresesinden mezun olursa kendisine ehliyetname ile taşra rüûsu hümayunu verilecektir. Ihtisas yapmak isteyenler ise Medresetü'lMütehassısîn'deki Tefsir-Hadis, Fıkıh ve Usûl-i Fıkıh, Kelam ve Hikmet Şubelerinin birinde öğrenimine devam ederek hazırlayacakları risalenin (tez) ilgili şube müderrisleri tarafından kabul edilmesiyle mezun olmaya hak kazanacaklar ve icazetname ile birlikte İstanbul rüusu pâyesini alacaklardır. ${ }^{17}$ Kitapta daha sonra çeşitli aşamalardaki ders programlan verilmektedir. ${ }^{18}$

II. Meşrutiyet yıllarında medreselerin ıslahı çalı̧̧maları çerçevesinde kurulan Darü'l-Hilafe Medreseleri'nin o dönemin anlayışı içinde örnek medrese tipini oluşturduğu ve yaygınlaştırılmasının hedeflendiği görülmektedir. Nitekim daha sonra 1921 yılında hazırlanan Medâris-i İlmiye Nizamnamesi'nin esbâb-1 mûcibe lâyihasında da Ankara Hükümeti'nin kontrolü altındaki yerlerde 14 Dârü'l-Hilâfe Medresesi bulunduğu ve sayılarının çok az olduğu, bunların her tarafta açılmalarının mâlî imkansızlıklar yüzünden mümkün olmadığı; ancak din görevlisine duyulan ihtiyacın karşılanabilmesinin de bir zaruret olduğu için eski tarz medreselerin Medâris-i Ilmiye adıyla yeniden düzenlendiği belirtilmektedir. ${ }^{19} \mathrm{Bu}$ ifadelerden, medreselerin tamamının Dârü'l-Hilâfe Medreseleri şeklinde düzenlenmesinin hedeflenmesine rağmen mâlî imkansızlıklar yüzünden gerçekleştirilmesinin mümkün olamadı̆̆ı, bununla birlikte mevcut medreselerin belirli bir intizama sokulması da zaruret teşkil ettiğinden şimdilik Medâris-i İlmiye adıyla yeni bir teşkilatın oluşturulduğu anlaşılmaktadır.

1921 yılında hazırlanan nizamname ile de Dârü'l-Hilâfe Medreseleri'nin mevcut ilmî yapısı korunmuş, bu medreselerin teşkilat ve idaresinin başka bir talimata bağlı olduğu ifade edilmiştir ${ }^{20} \mathrm{Bu}$ ifade, söz konusu medreselerin idaresi hususunda 1917 yılında yapılan son düzenlemenin TBMM Hükümeti'nin idaresi altındaki bölgelerdeki Dârü'l-Hilâfe Medreseleri için de geçerli olduğunun kabul edildiği şeklinde anlaşılmalıdır. Nitekim 1923 yılında TBMM Hükümeti Umur-1 Şer'iye ve Evkaf Vekâleti Tedrisat Müdüriyet-i Umumîsi tarafından yapılan ders programlanı ve müfredat düzenlemesi çalışmasında bu medreseler için 1917 yılında belirlenen ilmî yapı eski şekliyle korunmuştur. ${ }^{21}$ Bununla birlikte Dârü'l-Hilâfe Medreseleri'nin idaresi için 1922 yılında ayn bir talimat da hazırlanmış;

17. "Dârü'l-Hilafeti'l-Aliyye Medresesi ve Medresetü'l-Kuzât Nizamnamesi", s. 3-4.

18. "Dârü'l-Hilafeti'l-Aliyye Medresesi ve Medresetü'l-Kuzât Nizamnamesi", s. 5-9.

19. "Medaris-i Ilmiye Nizamnamesi Esbâb-ı Mûcibe Lâyihası", s. 3-4.

20. "Medaris-i Ilmiye Nizamnamesi", mad. 1.

21. Krş. Dârü'l-Hilâfe Medreseleri Ders Cetvelleri ve Müfredat Programı, Ö güt Matbaası, Ankara, 30 Rebiülevvel 1342/10 Teşrinisâni 1339 (10 Kasım 1923). 
ancak bu talimat da yine 1917 yllındaki düzenlemeden çok farklı olmayıp onun açılımı niteliğindedir. ${ }^{22} 107$ maddeden oluşan talimatla medreselerin idaresi, müderrislerin atanma ve görevlendirilme usulleri, talebelerin medreseye kabul şartlan, görevleri, imtihanlar ve mezunların görev alanlanı ile ayrıntılı düzenlemeler yapılmış; ancak ders programlarına yer verilmemiştir.

Şurası gözden kaçırılmamalıdır ki üzerinde çalışma yapılan ve geliştirilen medrese tipi 1914 yılındaki çalışmalar sonucunda ortaya çıkan ve ilki İstanbul'da açılan Dârü'l-Hilâfe medresesidir. Daha sonralan taşrada, yukarıda sözünü ettiğimiz bazı merkezlerde açılan Dârü'l-Hilâfe Medreseleri ilmî yapı, öğretim süresi ve programı itibarıyla İstanbul'dakine benzemeyen özellikler taşımakta ve orta dereceli öğretim kurumları olarak düzenlenmektedir. Halbuki 1921 yılında TBMM tarafından yapılan çalışmada bu medreselerin sadece programları geliştirilmekle kalmamış aynı zamanda bütün öğretim basamakları ile yaygınlaştırılmasına da çalışılmıştır.

Medâris-i İlmiye Nizamnamesi'nin ilk maddesinde Dârü'l-Hilâfe medreselerinin idaresinin başka bir talimatla belirlendiğinden bahsetmiştik. Aynca hazırlandığı anlaşılan bu talimatname ile getirilen hükümler büyük oranda Dârü'l-Hilâfeti'l-Aliyye Medresesiyle Taşra Medarisi Hakkında Nizamname'de getirilen hükümlerle uyum göstermekte; ancak bazı yerlerde farklılıklar görülmektedir ki bunlann başında medreselerin bağlı olduklan resmî mercî gelmektedir. Nizamnamede bu konuda Meşihat Makamı ve buna bağlı Meclis-i Mesalih-i Talebe'den söz edilirken yeni talimatnamede bunların yerini Şer'iye Vekâleti ve buna bağlı bir alt birim olan Tedrisat Müdüriyet-i Umumiliği almıştır. Buna rağmen geneli itibarıyla bakıldığında talimatnamenin söz konusu bu nizamnameyi çok geniş olarak esas aldığ açıkça görülmektedir.

Talimatnamede belirlenen giriş şartları, Dârü'l-Hilâfeti'l-Aliyye Medresesiyle Taşra Medarisi Hakkında Nizamname'de belirlendiği şekliyle korunmuştur. Buna göre medresenin İptida-yı Hâriç birinci sınıfına, yaşları $13^{\prime}$ ten aşağı ve $18^{\prime}$ 'den yukarı olmayan, bu medresenin hazırlık sınıfı veya iptidai mektebi mezunları kabul edilecektir; ancak hazırlık sınıfı mezunlan yeterli sayıda olmaz ise bu sınıftaki derslerden yapılacak imtihanda başarılı olacak diğer mektep mezunlarından belirlenen yaşlar arasında olanlar da kabul edilebilecektir. Medrese-i Süleymaniye'ye kabul edilmek için imtihan gerekirken diğer öğretim kademeleri için bir önceki kademeden mezun

22. Talimatnamenin metni için, Bk. "Dârü'l-Hilâfeti'l-Aliyye Medâris Talimatnamesi", "Medâris-i Ilmiye Nizamnamesi". Şehzadebaşı Evkâf-1 İslamiye Matbaası, 1338-1341 (1922), s. 16-37. 
olmak yeterli görülmektedir. Yine ara sınıflardan öğrenime başlamak isteyen talebeler, önceki sınıfların derslerinden imtihan edileceklerdir. Nizamnamede yer verilen, medreseye her yıl alınacak talebe sayısının Makam-1 Meşihat tarafından belirleneceği ile medreselerin çeşitli öğretim basamaklarına gündüzlü ve dinleyici (sâmiîn) talebelerin alınabileceğine dair esaslara talimatta yer verilmemekte, ${ }^{23}$ dolayısıyla bu hükümler TBMM Hükümetinin kontrolü altındaki medreseler için geçersiz bırakılmaktadır.

Dârü'l-Hilâfe medreselerinin idarî teşkilatının başında merkezde Şer'iye Vekâleti bulunmaktadır. ${ }^{24}$ Talimatnameye göre bu medreselerin Vekâlet'e bağlı Tedrisat Müdüriyet-i Umumiliği'ne bağlı olduğu anlaşılmaktadır; zira mesela disiplin konusunda alınan bazı kararlar bu merciye bildirilmek durumundadır. Aynı şekilde Dârü'l-Hilâfe medreselerinin müdür ve müderrislerinin tayin ve görevden alınma işlemleri Tedrisat Müdüriyet-i Umumiliği'nin teklif ve bildirmesi sonucunda Şer'iye Vekâleti tarafından gerçekleştirilmektedir. ${ }^{25}$ Mevcut haliyle söz konusu Vekâlet'in, Şeyhulislamlık Makamı'na benzer bir yapısının olduğu görülmektedir. Osmanlı Devleti içeresinde medreselerin eğitim öğretim işlerinin idaresinin Şeyhulislamlığın Meclis-i Mesâlih-i Talebe adlı birimi tarafından yürütüldüğü bilinmektedir. ${ }^{26}$ Nitekim 1917 tarihli nizamnamede de müderrislerin tayin ve görevden alınmalarının Meclis-i Mesâlih-i Talebe'nin kararı üzerine Meşihat tarafından gerçekleştirileceği ifade edilmektedir. ${ }^{27}$

Talimatnameye göre medreselerin idaresinden ve eğitim-öğretimin düzenli yürütülmesinden öncelikle müdürler sorumludur. ${ }^{28} \mathrm{Her}$ medresede müdürün başkanlığında müderris ve muallimlerin katılımıyla "Meclis-i Muallimîn" oluşturulacaktır. Her ay toplanacak bu meclisin görevi, devam eden eğitim-öğretim faaliyetlerini değerlendirerek gerekli değişiklik ve düzenlemeleri teklif etmek, talebeye bir ay boyunca verilecek vazifeleri tesbit etmek, müdür tarafından havale edilen konuları görüşmek, ayrıca derslerinde ve davranışlarında problemleri olan talebelerin durumlarını

23. Krş. "Dârü'l-Hilâfeti'l-Aliyye Medresesiyle Taşra Medarisi Hakkında Nizamname". mad. 21-26; "Dârü'l-Hilâfeti'l-Aliyye Medâris Talimatnamesi", s. 35.

24. Şer'iye Vekâleti'nin kuruluşu ve görevleri hakkında bilgi için, Bk. Mehmet Bulut, Türkiye Büyük Millet Meclisi'nde Din Eğitimi Hizmetleri ve Dini Yayın Konularında Yapılan Müzakereler Üzerine Bir Araşırma, Ankara Üniversitesi Sosyal Bilimler Enstitüsü, Basılmamış Yüksek Lisans Tezi, Ankara 1991, s. 15-17.

25. "Dârü'l-Hilafeti'l-Aliyye Medâris Talimatnamesi", mad. 20-21.

26. Uzunçarşılı, Ilmiye, s. 199.

27. "Dârü'l-Hilafeti'l-Aliyye Medresesiyle Taşra Medarisi Hakkında Nizamname", mad. 12.

28. "Dârü'l-Hilâfeti'l-Aliyye Medâris Talimatnamesi", mad. 3-4. 
görüşerek çözüm konusunda gerekli tedbiri almaktan ibarettir. Bunun dışında günümüzdeki okullarda Disiplin Kurulu görevini yerine getiren "İnzibat Meclisi" adıyla başka bir kurul oluşturulmaktadır ki bunun da vazifesi talebenin disiplinle ilgili durumlarını görüşmek ve karara bağlamaktır. Talebenin medreseden uzaklaştırılması dışındaki cezalar bu meclis tarafından, uzaklaştırma cezası ise Tedrisat Müdüriyet-i Umûmî tarafından verilebilir. ${ }^{29}$

Medreselerde görevlendirilecek müdür ve müderrislerin göreve atanmaları veya görevden alınmaları Tedrisat Müdüriyet-i Umûmîyesi'nin kararı ile Şer'iye Vekâleti tarafından yapılır. Atanacak müderrislerden hazırlık sınıfları dışındakilerde görev alacaklarda dersiâm, yüksek okul veya öğretim alanında uzman olma şartı aranmaktadır. ${ }^{30}$ Medresede görevli müdür, kâtip gibi idarî görevi olanlarla hazırlık sınıfında görevli muallimlerin bunun dışında ikinci bir görevde bulunmaları söz konusu değildir. Yine grup halinde bulunup haftada altı saatten fazla olan dersler medrese dışında muallimlikten başka resmî görevi bulunan kimseye, o dersi okutabilecek ehil kimse olduğu takdirde verilemez. ${ }^{31}$ Bu hükümlerle birlikte, medreselerde kaliteli bir öğretimin yapılabilmesi için gerekli görülen müderrislerin derse devamları, izinleri, görevden ayrılma istekleri ve uymaları gereken kurallar gibi düzenlemelere talimatta yer verilmektedir. 32

Talimatta eğitim-öğretim süresinin her yıl Eylül başından Mayıs sonuna kadar devam edeceği, derslerin Ramazan ayında öğleye kadar ve müzakere şeklinde yapılacağı ifade edilerek, günlük ders süresi hakkında ise sadece ders süresinin bir saat olduğu belirtilmektedir. ${ }^{33} \mathrm{Bu}$ süre daha sonra 1923 yılındaki program düzenlemesinde Tâli Kısm-1 Evvel (İptidâ-yı Hâriç) sınıflarında 50 dakika olarak sınırlandırılmıştır.

Öğretimde kullanılacak yöntemler konusuna da yer verilen talimatta müderrislerin Tefsir, Hadis, Sarf-Nahiv, Belâgat ve Edebiyat-1 Arabiye dersleri dışındaki din ile ilgili derslerde metin tahlili ile uğraşmadan konuları tam bir açıklıkla ve örnekler vererek anlatmaları istenmektedir. Yine müderrislerin derslerini gayet canlı bir şekilde anlatarak, talebelerin mesleğe karşı arzu duymalarını sağlamaları, her firsatta Islâm büyüklerinin hayatlanndan örnekler vermeleri, öğretim alanları dışında kalan konulara ders içinde yer vermekten kesinlikle kaçınmaları gerektiği belirtilmektedir ${ }^{34}$

29. "Dârü'l-Hilâfeti'l-Aliyye Medâris Talimatnamesi", mad. 14-20.

30. "Dârï'l-Hilâfeti'l-Aliyye Medâris Talimatnamesi", mad. 21-22.

31. "Dârü'l-Hilâfeti'l-Aliyye Medâris Talimatnamesi", mad. 12-13.

32. "Dârü'l-Hilâfeti'l-Aliyye Medâris Talimatnamesi", mad. 28-30,32.

33. "Dârü'l-Hilâfeti'l-Aliyye Medâris Talimatnamesi", mad. 27, 35-36.

34. "Dârï̀'l-Hilâfeti'l-Aliyye Medâris Talimatnamesi", mad. 24-26. 
Eğitim-öğretimde önemli bir aşama olan ölçme-değerlendirme konusuna talimatta müstakil bir bölüm ayrılmıştır. Öğretim yılı içinde yazılı olarak toplam üç imtihanın yapılması söz konusu edilmektedir. Bunlardan ikisi yıl içinde yazılı olarak ve ilgili dersin müderrisinin değerlendirmeyi kendisinin yaptığı imtihanlardır. Bu imtihanlarda sorulacak sorular dersin müfredatı dikkate alınarak dersin müderrisi ile müdür tarafından belirlenecektir. Dersin müderrisi imtihan sonucunu bir hafta içinde idareye teslim etmek zorundadır. ${ }^{35}$ Y 1 l sonu imtihanları ise Haziran ayında sözlü olarak, dersin müderrisinin yanısıra iki üyenin daha katılımı ile oluşturulan üç kişilik bir heyet huzurunda yapılacaktır. Şayet üyeler arasında takdir edilecek not hususunda bir ayrıllk olursa her üçünün toplam notunun ortalaması esas alınacaktır. Talebenin bir dersteki genel başarısı ise yazılı ve sözlü imtihanlardan aldığı notların ortalaması dikkate alınarak belirlenecektir. 36

Bu imtihanların yanında yıl içinde yapılan diğer ara değerlendirmelere de yer verilecektir. Öğretim yılı içerisinde müderrisler, İhzarî ve Itptida-yı Hâriç sınıflannda iki-üç derste bir zorunlu olarak, Íptidâ-yı Dâhil ve Sahn sınıflarında ise gerekli gördüğü zamanlarda talebeleri daha önce görülen derslerden sözlü olarak imtihan ederek takdir ettiği notu kaydedecek ve yıl sonundaki imtihanda bu notlan dikkate alacaktır. Hatta müderrisler gerek gördüklerinde ders saatleri dişında müdüre haber vermek şartıyla belirleyecekleri bir saatte talebeyi ayrıca imtihan edebilecektir. ${ }^{37}$ Öyle anlaşılıyor ki son bahsettiğimiz değerlendirme çalışmalanı daha çok talebenin derslere hazırlıklı gelmeleri ve düzenli çalışma alışkanlığı kazanmaları için yapılmakta ve belirli bir oranda da genel başarıya katılmaktadır.

Başarının değerlendirilmesi 10 tam puan üzerinden yapılacak ve talebenin başanlı sayılabilmesi için alınması gereken en az puan 5 olacaktır. Başarılı kabul edilen puanların sinıflandırılması ise 5-6 vasat (orta), 7-8 âlâ (iyi) ve 9-10 aliyyülâlâ (pekiyi) şeklinde olacaktır. ${ }^{38}$ Hazırlık sınıfı ile İptidâ-yı Hâriç ve Dâhil'de iki dersten, Sahn'da ise bir dersten başarısız olanlar bütünlemeye, daha fazla dersten başarısız olanlar ile bütünlemelerde de başarısız olanlar ise doğrudan sınıfta bırakılacaktır. Bir sınıfı en çok iki yılda geçemeyenlerin kaydı silinecektir. ${ }^{39}$

Öğretim yılının sonunda imtihan sonuçlarından elde edilen notlarla birlikte heyet, o yll yaplan derslerle ilgili olarak tenkit ettikleri ve

35. "Dârü'l-Hilâfeti'l-Aliyye Medâris Talimatnamesi", mad. 80-82.

36. "Dârü'l-Hilâfeti'l-Aliyye Medâris Talimatnamesi", mad. 35, 83, 88.

37. "Dârü'l-Hilâfeti'l-Aliyye Medâris Talimatnamesi", mad. 33-34.

38. "Dârü'l-Hilâfeti'l-Aliyye Medâris Talimatnamesi", mad. 87, 106.

39. "Dâriü'l-Hilâfeti'l-Aliyye Medâris Talimatnamesi", mad. 98-100. 
düzeltilmesini gerekli gördükleri hususlan, muallimler ise bir yıllık kanaatlerini, imtihan sonuçlan ve daha yüksek başanının elde edilmesi hakkında görüşlerini rapor halinde medrese müdürüne, o da hem imtihan hem de gelen raporları Tedrisat Müdüriyet-i Umumiliği'ne ulaştıracaktır.40

Medreseden ayrılan ya da mezun olan talebelere öğrenim durumlarını gösteren belgeler verilecektir. Hazırlık kısmını bitiren veya medresenin daha sonraki sınıflarından ayrılan talebelere medrese müdürünün onayladığı bir tasdikname verilecektir. Şehadetname ve icazetnamelerde ise talebenin öğrenim gördüğü sürece okuduğu bütün derslerden aldığı başarı notları ile genel başarı ortalaması yer alacak; medresedeki görevlilerle Tedrisat Müdüriyet-i Umumiyesi, icazetnameler ayrıca Şer'iye Vekaleti tarafından onaylanacaktır. ${ }^{41}$ Talimatta, tasdikname dışındaki belgelerin kimlere verileceği hususunda açık bilgi bulunmamaktadır. İcazetin, şehadetnameden daha yüksek bir öğrenim derecesi için verildiğini rahatlıkla ileri sürebiliriz. Şehadetnamenin, hazırlık sınıfından sonra Medrese-i Süleymaniye'ye kadarki basamakları bitirenlere, icazetin ise sadece Medrese-i Süleymaniye mezunlanna verildiğini tahmin ediyoruz. Nitekim 1917 tarihli nizamnamede Medrese-i Süleymaniye mezunlarına icazetname İptidâ-yı Hâriç ve Dâhil ile Sahn mezunlarına ehliyetname verileceği ifade edilmektedir. ${ }^{42}$

Talimatta oldukça geniş denilebilecek şekilde yer verilen hususlardan birisi de talebenin disiplini ve kontrolü için getirilen esaslardır. Genel olarak bakıldığında getirilen hükümlerden talebelerin derslere devamlarının sağlanması ile birlikte din eğitimi ve öğretimi gören bir insanın taşıması gereken ahlâk ve davranışlara sahip olmalarının temin edilmesi amacı olduğu anlaşılmaktadır. Bir öğretim yılında toplam 30 derse girmeyen talebe yıl sonu imtihanlarına giremeyecek, yine bir öğretim yılı içinde 30 gün devamsızlık yapanların ise kayıtları silinecektir. ${ }^{43}$ Talebelerden gerek medrese içinde ve dersler esnasında gerekse medrese dışındaki davranışlanında, son derece önemli sorumlulukları olan ilmiye mesleğinin mensuplanı olduklarını unutmayarak dikkatli ve ölçülü olmaları istenmektedir. Talebelere kazandırılması hedeflenen ve birer düstur niteliği taşıyan birtakım esaslar belirlenmiştir : "Fazilet-i ahlâkiye olmadıkça yalnız başına ilim ve maarifin hiçbir menfaat temin edemeyeceğini her bir talebe kat'i bir düstur olarak

40. "Dârü'l-Hilâfeti'l-Aliyye Medâris Talimatnamesi", mad. 93-95.

41. "Dârü'l-Hilâfeti'l-Aliyye Medâris Talimatnamesi", mad. 102-104.

42. "Dârü'l-Hilâfeti'l-Aliyye Medresesiyle Taşra Medârisi Hakkında Nizamname", mad. 28.

43. "Dârü'l-Hilâfeti'l-Aliyye Medâris Talimatnamesi", mad. 37. 
zihnine yerleştirecektir", 44 "Talebe kavî bir bedene, asil bir fikre, metin bir ahlâka sahip, büyük bir İslâm âlimi olmak için kuvvâ-yı bedeniye, kuvvâ-yı fikriye ve ahlâkiyesinin terakkisine itina ve bunu kendisi için bir vazife telakki edecektir". ${ }^{45} \mathrm{Bu}$ çerçevede talebelerin doğruluktan ayrılmamaları, saygılı olmalan ve temizliğe riayet etmeleri, ayrıca siyasetle uğraşmamaları ve hiçbir siyasî partiye girmemeleri gerektiği gibi hususlara da yer verilmektedir. ${ }^{46}$

Mezunların istihdam alanlan da 1917 tarihli nizamnamede belirtildiği şekliyle korunmuştur. ${ }^{47}$ Buna göre Medrese-i Süleymaniye mezunlan ihtisas alanlarına göre Dârü'l-Hilafe Medresesi müderrisliği ile idareciliği, diğer mekteplerdeki Ulûm-1 Diniye ve Arapça dersleri muallimliği, vâizlik, müftülük, sefaret ve alay imamlıklan ve bunlara denk diğer görevlere atanabileceklerdir. Sahn mezunlan ise Evkâf ve müftülük memuriyetleri, İptidâ-yı Hâriç ve Dâhil medresesi müdürlük ve muallimliklerine, ilmiye medresesi müderrisliklerine, İptidâ-yı Dâhil mezunları şehirlerdeki camilere imamlık, kütüphane memurlukları (hâfız-1 kütüp) ve iptidailere din dersleri muallimliklerine, İptidâ-yı Hâriç mezunlan köy camilerinin imam ve hatiplikleri ile muallimliklerinde ayrıca bunlara denk görevlerde istihdam edileceklerdir. ${ }^{48}$

\section{Medâris-i İlmiye}

Bu isim Medâris-i İlmiye Nizamnamesi'nde Dâru' l-Hilâfe medreseleri dışında kalan medreseler için kullanılmaktadır. Daha önce de bahsettiğimiz gibi yaygınlaştırılması hedeflenen örnek medrese tipi Dârü'l-Hilâfe medreseleridir; ancak bütün medreselerin bu tarzda düzenlenme imkanının olmaması yüzünden dışarıda kalan medreseler mevcut ihtiyacın karşılanması amacıyla Medâris-i Îlmiye adı altında düzenlenmişlerdir. Söz konusu nizamnamenin hazırlanış amacı İlmiye Medreseleri'nin kuruluşu ve düzenli bir yapıya kavuşturulmasıdır. Bu çerçevede medreselerin idaresi, öğretim kadrosu, ders programı ve öğretim süresi ile talebeler hakkında çeşitli hükümler getirilmiştir.

Ilmiye medreseleri tıpkı Dârü'l-Hilâfe medreseleri gibi Şer'iye Vekâleti'ne bağlı olup bu merciin uygun gördüğu yerlerde ve sayıda

44. "Dârü'l-Hilâfeti'l-Aliyye Medâris Talimatnamesi", mad. 54

45. "Dârü'l-Hilâfeti'l-Aliyye Medâris Talimatnamesi", mad. 55.

46. "Dârü'l-Hilâfeti'l-Aliyye Medâris Talimatnamesi", mad. 46, 58-63.

47. Krş. "Dârü'l-Hilâfeti'l-Aliyye Medresesiyle Taşra Medarisi Hakkında Nizamname", mad. 33-37; Dârü'l-Hilâfeti'l-Aliyye Medâris Talimatnamesi, s. 36-37.

48. Dârü'l-Hilâfe medresesi mezunlarının istihdam alanları ile ilgili konuya Talimatın son kısmında yer verilmiştir. 
açılabilecektir.49 Medreselerin mahallî idareleri ise müftülerin oldukları yerlerde müftünün başkanlığında şimdilik Evkaf memuru ve ulemadan üç kişinin katılımı ile toplam beş kişiden, sonraki dönemlerde ise medreselerde görevli müderris ve muallimlerden oluşan ve görev süresi bir yıl olan Medrese-i Illmiye Encümenleri tarafından gerçekleştirilecektir. Encümenlerin görevi medreseleri denetlemek, eğitim-öğretim için gerekli donanımı sağlamak, dersleri okutacak müderris ve muallimleri belirleyerek isimlerini özgeçmişleri ile birlikte Şer'iye Vekâleti'ne bildirmek ve medreseye kaydolunan talebelerin künye defterini tutmak olarak belirlenmiştir. ${ }^{50}$

Medresenin ilk sınıfına 12-17 yaşlar arasında talebelerin kaydedilmesi esas olmakla birlikte yaşı bu sınırlardan aşağı olanların, medresedeki bir yakınının yanında kayıtsız olarak kalarak mektebe devam etmesine izin verilmektedir. Yine yaşı büyük talebelerin imtihan edilerek ileri sınıflara kabul edilmelerine de imkân tanımaktadır. Ilk sınıfa kabul edileceklerin Türkçe okuma-yazma ve Kur'an okumayı bilmeleri, sıbyan mektebi mezunu veya bu derecede öğretim görmüş olmalan gerekmektedir. ${ }^{51}$

İlmiye medreselerinin toplam 12 yıllık öğretim süresinin ilk 6 yılı Kısm-ı Evvel, ikinci 6 yılı ise Kısm-ı Sânî olarak tanımlanmıştır ki bu durum İlmiye medreselerinin orta dereceli medreseler olarak düzenlendiğini ortaya koymaktadır. İlk kısımda günde üç, ikinci kısımda ise iki ders okunacak ve Cuma dişında her gün derslere devam edilecektir. ${ }^{52}$

Medresenin nizamname ile belirlenen programında şu dersler bulunmaktadır:

TABLO 1 : 1921 Medaris-i İlmiye Nizamnamesi'ne Göre İlmiye Medreselerinin Ders Programı

\section{Kusm-1 Evvel}

\begin{tabular}{|c|c|c|c|c|c|c|}
\hline DERSLER & 1. Sinif & 2. Sinif & 3. Sinif & 4. Sinif & 5. Sinif & 6. Sinif \\
\hline$\overline{\text { Sarf }}$ & $\overline{5}$ & $\overline{-}$ & - & $\overline{-}$ & $\overline{-}$ & $\overline{-}$ \\
\hline Tertil-i Kur'an & 4 & - & - & - & - & - \\
\hline Lügat-i Arabiye & 3 & 2 & - & - & - & - \\
\hline Imla ve Kıraat & 2 & 2 & - & - & . & - \\
\hline Hesap & 2 & 2 & 2 & - & - & - \\
\hline Hat & 2 & 2 & - & - & - & - \\
\hline Avâmil ve İzhar & - & 5 & - & . & - & - \\
\hline
\end{tabular}

49. "Medâris-i llmiye Nizamnamesi", mad. 2.

50. "Medâris-i llmiye Nizamnamesi", mad. 4-5.

51. "Medâris-i llmiye Nizamnamesi", mad. 9-11.

52. "Medâris-i llmiye Nizamnamesi", mad. 3. 


\begin{tabular}{|c|c|c|c|c|c|}
\hline Halebî & - & 4 & 4 & - & - \\
\hline Arabî & - & 1 & - & - & - \\
\hline Molla Câmî & - & - & 5 & 5 & - \\
\hline Merah & - & $\cdot$ & 2 & - & - \\
\hline Kavâid-i Osmaniye & - & - & 2 & - & - \\
\hline Cografya & - & - & 2 & 2 & - \\
\hline Kıraat-1 Arabiye & - & - & 1 & - & - \\
\hline Kudûnî & - & - & - & 5 & - \\
\hline Kavâid ve Kitâbet & - & - & - & 2 & - \\
\hline Hendese & - & - & - & 2 & - \\
\hline Ísagoji ve Alâka & - & - & - & 2 & - \\
\hline Mantık & - & - & - & - & 5 \\
\hline Mülteka (veya İgâsetư’t Tâlibîn) & - & - & - & - & 5 \\
\hline Vaz' & - & - & $\cdot$ & - & 1 \\
\hline Farisî & - & - & - & - & 2 \\
\hline Kitabet veya Edebiyat-1 Türkiye & - & - & - & - & 2 \\
\hline Tarih-i Osmanî & - & - & - & - & 2 \\
\hline Ferâiz & - & - & - & - & 1 \\
\hline Adâb & - & - & - & - & $\cdot$ \\
\hline Tarih-i İslâm & - & - & - & - & - \\
\hline Gülistan & - & - & - & - & - \\
\hline Nûniye & - & - & - & - & - \\
\hline Toplam & 18 & 18 & 18 & 18 & 18 \\
\hline
\end{tabular}

\section{Kısm-1 Sânî}

\begin{tabular}{|c|c|c|c|c|c|c|}
\hline DERSLER & 7. Sinif & $\underline{\text { 8. Sinif }}$ & 9. Sinif & 10. Sinif & 11. Sinıf & 12. Sinif \\
\hline Kelam & 5 & 5 & 5 & 5 & - & - \\
\hline Muhtasar Meânî & 5 & 5 & - & - & - & - \\
\hline Ferâiz & 2 & - & - & - & - & - \\
\hline Hifzı's-Sıhha & 1 & - & - & - & - & - \\
\hline Edebiyat-1 Arabiye & - & 2 & - & - & - & - \\
\hline Tarih-i Umumî & - & 2 & 2 & - & - & - \\
\hline Usul-i Fikıh & - & - & 2 & 5 & 5 & - \\
\hline Ahlâk & - & - & 2 & - & $\cdot$ & - \\
\hline Usul-i Hadis & - & - & - & 2 & - & - \\
\hline Medeniyet-i İslâmiye Tarihi & - & - & - & 2 & - & - \\
\hline Tefsir ve Hadis & - & - & - & - & 5 & 5 \\
\hline Mecelle & - & - & - & - & 2 & - \\
\hline Dürer (Muamelat Kısmı) & - & - & - & - & - & 5 \\
\hline Şifa & - & - & - & - & - & 2 \\
\hline Toplam & 13 & 14 & 11 & 14 & 12 & 12 \\
\hline
\end{tabular}


İlmiye medreselerindeki imtihanların düzenlenmesi amacıyla 8 maddelik ayrı bir talimatname hazırlanmışıิır.53 Talimata göre imtihanlar sıcak bölgelerde Mayıs, diğer yerlerde ise Haziran ayında yapılacaktır. Arapça ibarelerin okutulduğu derslerde tam not 20 diğerleri için ise 10 olarak kabul edilmekte, talebelerin başarılı kabul edilmeleri, dolayısıyla sınıf geçebilmeleri için en az 20 üzerinden 8 veya 10 üzerinden 4 puan almaları gerekmektedir. Bütünleme imtihanı ancak iki dersten başarısız olanlar için geçerli olup daha fazla dersten başarısız olanlar, herhangi bir sebepten imtihanlara katılamayanlar ve bir öğretim yılında üç ay devamsızlık yapanlar doğrudan sınıfta bırakılacak, iki yıl üst üste sınıfta kalanların ise kayıtlanı silinecektir. Kısm-1 Evvel imtihanlarında, imtihan heyeti arasında mahallin en büyük mülkî ve askerî memurları ile kadı ve Encümen-i İlmî'nin belirleyeceği biri ilgili dersin müderrisi dört kişi yer alacak, Kısm-1 Sânî imtihanlarında ise bu heyete ayrıca Müdafaa-i Milliye Vekâleti'nden gönderilecek bir üye de katılacaktır.

İmtihanlar konusu içinde medrese talebelerinin de tâbî oldukları kur'a imtihanlarına temas etmek gerekir; zira her ne kadar bu imtihanlar medrese öğretimindeki başarının ölçülmesi için değil ise de talebelerin askerlikleri nedeniyle öğrenimlerine devam edip edemeyeceklerinin belirlenmesi açısından önem taşımaktadır. Hazırlanan talimatın ilk maddesinde medreselerde her yılın sonunda umumî imtihanlar yapılacağından kur'a imtihanlarının kaldırıldığı belirtilmektedir. Diğer taraftan, gerek medrese gerekse diğer mekteplerdeki muallim ve talebelerin askerliklerinin düzenlenmesi konusunda da çalışmaların yapıldığı görülmektedir. 1921 tarihinde yürürlüğe giren Muallimin ve Talebenin Askerlikten Tecilleri Hakkında Kanun'un ilk iki maddesine göre orta ve yüksek dereceli mekteplerle birlikte Dârül-Hilâfeti'l-Aliyye talebelerinin fiilî askerlik hizmetleri öğrenimlerini tamamlayıncaya, ilmiye medreselerine devam edenlerin ise ihtiyata ayrılmadan bir sene önceye kadar, hizmet-i maksureyi ${ }^{54}$

53. Talimatname, Nizamnamenin yayınlandığı kitapçığın içerisinde bulunmaktadır. Bk. "Medâris-i İlmiye İmtihanlanı Hakkında Talimatname", Medâris-i llmiye Nizamnamesi, Şehzadebaşı Evkâf-1 İslamiye Matbaası, 1338-1341, s. 12-13.

54. Talebclcrin askerlikleri ile konunun anlaşılabilmesi için kullanılan ifadelerin anlamlannın bilinmesi gerekecektir. Söz konusu ifadelerin anlamlarını, çalıştığımız dönemde de geçerli olduğunu bildił̧imiz 16 Cemaziyelâhir 1332/29 Nisan 1330 (11 Mayıs 1914) tarihli "Mükellefiyet-i Askeriye Kanun-1 Muvakkatı" "ndan, Bk. Düstur VI, II. Tertib, Matbaa-i Amire 1334, s. 662-704, ögrenmek mümkündür. Buna göre "fiilî askerlik" silah altında bulunma süresidir $\mathrm{ki}$ bu süre çeşitli sınıflara göre 2:5 yıl arasında değişmekte, daha sonra ise muvazzaflık ve mustahfazlık dönemleri gelmektedir. Mesela piyade sınıfında askerlik yapan bir kimsenin 2 yılı fiili , 23 yılı muvazzaf, 5 yıl da mustahfiz olarak toplam askerlik süresi 30 yıl olmaktadır. Hizmet-i maksure ise ögrenim görenlere kolaylık sağlanmak üzere geçerli olan bir yıl süreli kısaltılmış askerlik hizmetidir. (mad. 3-5, 42) 
ifa ettikten sonra tahsillerine devam etmek üzere ertelenecektir. 55 Yine aym kanunun 6. maddesi uyarınca, hâlen silah altında bulunanlardan kanundaki haktan istifade edecek müderris, muallim ve müdürler görevlerine devam etmek şartıly terhis edileceklerdir.

Dönem boyunca medrese talebelerinin askerlikleri konusunda söz konusu kanun hükümlerinin uygulanması sırasında ortaya çıkan bazı ayrıntıların açıklığa kavuşturulması ve kanunun uygulanışının takibi için sonraki yıllarda çalışmaların devam ettiği bu konudaki belgelerden anlaşılmaktadır. Şu hususu belirtmeliyiz ki 1921 yılında hazırlanan bu kanunun uygulanmasında daha önce 1914 yılında hazırlanan Mükellefiyet- $i$ Askeriye Kanun-ı Muvakkat $\imath^{56}$ esas alınmakta, yazışmalarda bu kanunun değişik maddelerine atıflarda bulunulmaktadır. Bu çerçevede ilk olarak 1921 y1lı sonlannda Müdafaa-i Milliye Vekâleti ile birlikte uygulamalara esas teşkil etmek üzere belirlenen bazı prensipler Şer'iye Vekâleti tarafından merkez müftülüklerine bildirilmiştir..$^{57}$ Bu prensipler arasında,

1. Mütarekeden önce silah altına alınmaları yüzünden tahsilleri yarım kalan medrese talebelerinin öğrenimlerine devam etmeleri şartıyla terhis edilecekleri,

2. Medreselere 18 yaşını doldurmuş ve daha yukarı yaştakilerin kaydedilmemeleri, 58

55. 21 Şubat $1337 / 13$ Cemaziyelâhir 1339 (21 Şubat 1921) tarihli bu kanunun metni için, Bk. "Muallimin ve Talebenin Askerlikten Tecilleri Hakkında Kanun", Düstur I, Ill. Tertib, Milliyet Matbaası, İstanbul 1929, s. 219-220.

56. 16 C. Ahire 1332/29 Nisan 1330 (11 Mayıs 1914) tarihli bu kanunun metni için. Bk. "Mükellefiyet-i Askeriye Kanun-1 Muvakkatı", Düstur VI, II. Tertib, Matbaa-i Amire 1334, s. 662-704.

57. Bu esaslara Şer'iye Vekâleti tarafından Muğla Müftülüğü'ne gönderilen yazıda yer verilmektedir. Bk. BCA. No: 051/13.113.6, 25 Kanunusânî 1338 (25 Ocak 1922). Yine Vekalet tarafından Izmit Müftülügü̈'ne gönderilen başka bir yazıda nizamname olarak bahsedilen bu esasların gönderildiği belirtilerek uyulması istenmektedir. Bk. BCA. No: 051/7.63.12, 24 Kanunusâni 1338 (24 Ocak 1922). Aynı muhtevalı yazıya Arşivdeki diğer bir kayıtta da rastladık; ancak bu yazının nereyc gönderildiği hakkında kayıt bulunmamaktadır. Bk. BCA. 051/3.15.3, 5 Kanunuevvel 1337 (5 Aralık 1921). Bu iki yazıdan 1921 yılı Aralık ayından itibaren bu esasların Ankara dışındaki müftülüklere gönderildiği anlaşılmaktadır.

58. Buna göre medreseye 18 yaşını dolduran yani askerlik çą̆ına gelenler kabul edilmemektedir. Nitekim Adapazarı'ndaki Kara Osman Ağa Medresesi hakkında bilgi verilen bir yazıda, 1317, 1318 ve 1319 dogumlulardan -ki bunlar 18, 19 ve yaşında olurlar - medrese tahsili arzu edenler bulunsa da bu yaşlarda bulunan talebelerin askerlik tecilinin mümkün olmadığı asker alma şubesinden bildirildiğinden medreselere rağbetin olmadığı ifade edilmektedir. BCA. No: 051/7.63.6. 5 Kanunusânî 1338/6 C. Evvel 1340 (5 Ocak 1922). 
3. 21 Şubat 1921 tarihli kanunun ilk maddesi gereğince, orta ve yüksek dereceli mekteplerde talebe iken ara vermeden öğrenimlerine devam edenlerin de askerliklerinin ertelenmesi; ancak kanun çıkmadan önce askere çağrıldığı hâlde gitmeyenlerin sağlanan kolaylıklardan faydalanamayacakları gibi konulara yer verilmektedir.

Medreselerin askerlik çağına gelenlerin sığınağı olmaması için gerekli tedbirler alınmakta, askerlik şubeleri bu hususta medreselerden bilgi isteyerek uygulamalar takip edilmektedir. Nitekim, İzmit ve Konya Askerlik Şubeleri tarafından ilgili müftülüklerden, medreselerde kayıtlı ve ders gören talebeler hakkında gerekli bilgileri taşıyan onaylı bir defter istenmekte, ayrıca medreselere yaşları uygun olmayanların kaydedilip kaydedilmediği ile kayıtlı talebelerin gerçekten derslere devam edip etmediklerini kontrol için teftişlerin yapılabileceği belirtilmektedir.59 Diğer taraftan medreselerde yapılan imtihanlarda asker̂̂ temsilcilerin de bulunması gerektiği Mükellefiyet-i Askeriye Kanunu'nun 142. maddesine atıfta bulunularak ifade edilmektedir. 60

Dârül-Hilâfe talebelerinin öğrenimlerinin sonuna kadar askerliklerinin ertelenmesi hükmü, daha sonra 1924 yılında hazırlanan diğer bir kanunun ilk maddesinin c fikrası ile talebelerin medreseye devam etmeleri şartıyla her yıl için yenilenerek erteleneceği şeklinde değiştirilmiştir. Yeni düzenlemeye göre talebelerin askerlikleri, derslerine devam ettiklerini belgelemeleri halinde bir sonraki yıla ertelenecek, yine aynı kanuna göre Dârül-Hilâfe Medresesinin tâlî kısmı ile İlmiye medreselerinin 8. sınıfını bitirenler hizmet-i maksureye tâbî olacaklardır. ${ }^{61}$

1921 yılında hazırlanan Medâris-i İlmiye Nizamnamesi'nin medreselerin ilga edildikleri 1924 yılına kadar ne derece ve nasıl uygulandığı konusu önem taşımaktadır. Öyle ki medreseler konusunda yapılan bu son çalışmanın uygulanmasından elde edilen başarı konusunda ortaya konulabilecek sonuçların, medreselerin ilgâ edilmelerini ne derece haklı kıldığı sorusuna da cevap olacağı kanaatindeyiz. Nizamnamenin uygulanması ve elde edilen başarı konusunda bizim burada başvuracağımız başlıca kaynaklar resmî nitelikteki belgeler olacaktır ki bu konuda Başbakanlık Cumhuriyet Arşivi'nde yeterli sayı ve nitelikte belge bulunmaktadır.

59. BCA. No: 051/7.64.46, 22 Teşrinisânî 1338 (22 Kasım 1922); BCA. No : 051/13.113.15, 27 Şubat 1338 (27 Şubat 1922).

60. BCA. No: 051/2.1.21, 20 Haziran 1339 (20 Haziran 1923).

61. "Muallimîn ve Talebenin Askerlikten Tecilleri Hakkındaki 21 Şubat 1337 Tarihli Kanuna Müzeyyel Kanun", 19 C. Ahir 1342/26 Kanunusânî 1340 (26 Ocak 1924), Düstur V, III. Tertib, Necm-i İstikbal Matbaası, İstanbul 1931. s. 587-588. 


\section{B. Medaris-i İlmiye Nizamnamesi'nin Uygulanması}

\section{Açılan Yeni Medreseler ve Talebe Sayzlan}

Nizamnamenin hazırlanmasından hemen sonra aynı yıl içinde uygulamaya başlandığı görülmektedir. Elde ettiğimiz bilgilere göre Şer'iye Vekâleti ilk olarak mevcut medreseler hakkında kapsamlı bilgiler toplama yoluna giderek mevcut durumu tesbit etmeye çalışmıştır. Nizamnamenin 2. maddesine göre medreselerin açılması Şer'iye Vekâleti'nin iznine bağh olduğundan nerelerde medreselerin açıldığı konusunda ve oluşturulan Encümen-i İlmîler ile imtihan sonuçları ve öğretim kadroları hakkında Vekâlet bilgi istemektedir.62 Nitekim İzmit Müftülüğü'ne Vekâlet tarafından gönderilen bir yazıda, müftülüğün sorumluluk bölgesindeki mevcut medrese sayısı ve bunların gelirleri, beratlı ve beratsız müderrisler ile müderrisi olmayan medrese sayısı, medrese binalarının öğretime ne derece elverişli olduklan, talebelere tahsisat sağlanıp sağlanamadığı konularında acele bilgi verilmesi istenmektedir. ${ }^{63}$ Verilen cevapta, kaza dahilinde Geyve kasabasında 24 talebesi olan bir medresenin açıldığı bildirilmektedir. ${ }^{64}$ Daha sonra Geyve Müftülüğü, söz konusu medrese hakkındaki bilgileri ihtiva eden bir cetveli İzmit Müftülüğü'ne göndermiştir. ${ }^{65}$

Medreselerin açılması konusunda her yerde aynı başarının gösterilemediği anlaşılmaktadır. Geyve Müftülüğü'nden yazılan diğer bir yazıda, Taraklı Nahiyesi'ndeki beş medreseden üçünün faal durumda olup yalnız bir tanesinin gelirinin olduğu, müderrislere maaş ödenemediği gibi tahsile arzulu kimselerin de bulunmadığ medreselerin faaliyete geçirilmesi için elden gelen gayret sarfedileceği ifade edilmektedir. ${ }^{66}$ İzmit'e bağlı Bahçecik Nahiyesi'nden intikal eden bilgiye göre mevcut medresede beş talebe bulunmakta ve Ramazan ayının girmesi dolayısıyla derslere ara verilmiştir ${ }^{67}$ Büyük ihtimalle burada da yeni teşkilat kurulmamış olmalıdır. Yine Izmit'e bağlı Kandıra Müftülüğü'nden yazılan yazıda, kazada seferberlikten önce üç sınıflı bir medresenin 86 talebesi ile tedrisata devam cttiği; ancak şu anda hiçbir talebenin bulunmadığ bildirilmektedir. 68

62. BCA. No: 051/7.64.40, 4 Teşrinisânî 1338 (4 Kasım 1922).

63. BCA. No: 051/7.64.43, 8 Teşrinisânî 1338 ( 8 Kasım 1922).

64. BCA. No: 051/7.63.4, 6 Kanunucvvel 1337 (6 Aralk 1921).

65. BCA. No: 051/7.63.5, 22 Kanunuevvel 1337 (22 Aralık 1921)

66. BCA. No: 051/7.63.24, 2 Mart 1338/2 Receb 1340 (2 Mart 1922).

67. BCA. No: $051 / 7.63 .32,15 \mathrm{Nisan} 1338$ (15 Nisan 1922).

68. BCA. No: 051/7.63.7, 10 Kanunusânî 1338/11 C. Ahir 1340 (10 Ocak 1922). 
Adapazarı'ndaki medresede 14 Eylül 1337 (14 Eylül 1921) tarihinde derslere başlanmış, esasen medresenin kapasitesi 50-60 talebeyi barındıracak kadar geniş olmasına rağmen imam, hatip, müezzin ve muallimlerden oluşan beş talebe ile öğretim devam etmekle birlikte; yeni nizamname ile getirilen teşkilat henüz kurulamamıştır.69 Adapazarı'nda ilmiye medresesinin ancak 26 Şubat 1922 tarihinden sonra faaliyete geçtiği anlaşılmaktadır. Konu ile ilgili bilgilerin yer aldığı belgeye göre öncelikle Encümen-i İlmî'nin kurularak talebe kabul edileceği ilan edilmiş, ardından da başvuran 27 kişi imtihan edilmiş ve yaşları da dikkate alınarak ikinci sınıfa kabul edilmişlerdir. Bunlardan altısı daha sonra ayrılmış ve yeni programın uygulanmasına 12 Mart $1922^{\prime}$ 'de başlanmıştır.70

Hendek'de de biri merkezde diğeri bir köyde olmak üzere iki medresede toplam 46 talebe eğitim görmektedir. ${ }^{71}$ Bu bilginin verildiği tarihten yaklaşık iki ay sonra faaliyete geçen ilmiye medresesinde ${ }^{72}$ Encümen-i Illmî'nin, nizamnamedeki esaslara uygun biçimde kurularak 1., 2., 5. ve 11. sınıfların oluşturulduğu, yaklaşı olarak 60-80 kadar talebenin bulunabileceğinin tahmin edildiği ifade edilmektedir; ${ }^{73}$ ancak daha sonra verilen bilgide medresenin birinci ve ikinci sınıfında toplam 19 talebenin bulunduğundan söz edilmesine rağmen diğer sınıflardaki talebe sayısına temas edilmemektedir ${ }^{74} \mathrm{ki}$ bu bilgiye dayanarak çalışmaların beklenen şekilde gelişmediği, ne talebe sayısının ne de açılması düşünülen sınıfların beklenen sayıya ulaşamadığını ileri sürmek mümkündür. Diğer taraftan, Hendek'teki medresenin açılması için gerekli izin Şer'iye Vekâleti tarafından verilmiştir ${ }^{75}$ ancak gerekli iznin medresenin açılmasından sonra istenmesi dikkati çekmektedir. Yine Muğla'ya bağı Ula'da da bir medresenin açılarak, tedrisata 11 Eylül 1922 günü ilk iki sınıfla başlandığı, Encümen-i İlmî’nin uygun görmesi halinde üçüncü sınıfın da tedrisata başlayabileceği Muğla Müftülüğü'ne gönderilen yazıdan anlaşılmaktadır. ${ }^{76}$

69. BCA. No: 051/7.63.6, 5 Kanunusânî 1338/6 Cemaziyelevvel 1340 (5 Ocak 1922).

70. BCA. No: 051/7.63.26, 26 Mart 1338 (26 Mart 1922).

71. BCA. No: 051/7.63.8, 13 Kanunusânî 1338/14 Cemaziyelevvel 1340 (13 Ocak 1922).

72. Yeni Cami Medresesi adlı bu medresenin resmî açılışının 22 Nisan 1922 tarihinde gerçekleştirildił̣̌i Izmit Müftülüưư'ne daha sonra bildirilmiştir. Bk. BCA. No: 051/7.64.30, 9 Eylül 1338 (9 Eylül 1922).

73. BCA. No: 051/7.65.25, 17 Mart 1338/18 Receb 1340 (17 Mart 1922)

74. BCA. No: 051/7.64.12, 18 Agustos 1338 (18 Agustos 1922).

75. Vekaletten İzmit Müftülüğü'ne gelen izin verildiğine dair yazıda, Müftülüüün 25 Mart 1338 (25 Mart 1922) tarihli yazısına cevap oldugu belirtilmektedir. BCA. No: 051/7.63.28, (3 Nisan 1922).

76. BCA. No: 051/13.113.55, 13 Eylül 1338 (13 Eylül 1922); BCA. No: 051/13.113.20, 10 Mart 1338 (10 Mart 1922). 
Medreselere kabul edilmek üzere başvuranlar arasında yaşı çok büyük olanların bulunduğu görülmektedir. Tedrisat Müdüriyet-i Umumiliği tarafından İzmit Müftülüğü'ne gönderilen bir yazıda, 1318 (20 yaş) doğumluların medresenin ilk sınıfına kabul edilemeyeceği; ancak 1319 (19 yaş) doğumluların imtihanı başarmaları halinde ikinci sınıfa kabul edilebilecekleri belirtilmektedir. ${ }^{77}$

Yeni nizamname çerçevesinde medreselerin açılışına sonraki yıllarda da devam edilmiştir. 1922 yılı sonunda Vekâlet merkez müftülüklerinden yeni medreselerin nerelerde açıldıklan ve her sınıfta kaç talebe bulunduğu hakkında bilgi istemektedir. ${ }^{78}$ Bu konuda Adapazan Müftülüğü'nden verilen cevapta kaza dahilinde iki sınıflı bir medresenin açıldığı bağlı diğer nahiye ve köylerde ise açılabilen yeni medresenin bulunmadığı bildirilmektedir. ${ }^{79}$

Şer'iye Vekaleti'nden gönderilen 1923 yılına ait bir yazıda Gümüşhacıköy'ün Gümüş nahiyesinde bir medresenin açllışının onaylandığı, ${ }^{80}$ yine Adapazarı'na bağlı Karasu'nun Kocaali köyünde halkın yardımlan ile yaptırılan iki hücreli medresenin faaliyete geçtiği ifade edilmektedir. ${ }^{81}$ Aynı yılın sonlanna doğru Geyve Müftülüğü'nden muallim ihtiyacının belirtildiği diğer bir yazıda medresede birinci sınıfta 5 , ikinci sinıfta 6 , üçüncü sınıfta ise 12 talebenin bulunduğu, askerlikten terhis edilen 9 talebenin de dördüncü sınıfa devam ettiği belirtilmektedir. ${ }^{82}$ Aynı hususta ve aynı yıl yine Hendek Müftülüğü'nden yazılan yazıda ise birinci sınıfta 3, ikinci sınıfta 5, üçüncü sınıfta ise 11 talebenin olduğu bildirilmektedir. ${ }^{83}$

Medreselerin denetiminin müftüler tarafından yapıldığı ve zaman zaman bilgiler istendiği görülmektedir. Nitekim Kocaeli Müftülüğu’nün talebi üzerine Hendek Müftülüğü mevcut medresedeki kayıtlı talebelerin isim ve sinıfları, müderris ve Encümen-i İlmî üyelerinin isim ve kısa hal tercemelerine dair bilgileri göndermiştir ${ }^{84}$

Bir yandan medreselerinin açılması ve yaygınlaştırılması çalışmalan devam ederken diğer taraftan asıl hedefin Darü'l-Hilâfe medreselerine geçiş olduğu da unutulmamaktadır. Vekâlet'ten 1923 yılında İzmir Müftülüğü'ne

77. BCA. No: 051/7.64.28, 5 Eylül 1338 (5 Eylül 1922).

78. BCA. No: 051/7.64.1, 1 Ağustos 1338 (1 Agustos 1922); BCA. No: 051/7.64.62, 27 Kanunusânî 1339 (27 Ocak 1923).

79. BCA. No: 051/7.64.10, 16 Agustos 1338/21 Zilhicce 1340 (16 Agustos 1922).

80. BCA. No: 051/2.1.15, 13 Kanunusânî 1339 (13 Ocak 1923).

81. BCA. No: 051/7.64.53, 6 Kanunusânî 1339 (6 Ocak 1923); BCA. No: 051/7.64.67, 19 Şubat 1339 (19 Şubat 1923).

82. BCA. No: 051/8.65.45, 15 Kanunuvvel 1339 (15 Aralık 1923).

83. BCA. No: 051/8.65.43, 11 Kanunuvvel 1339 (11 Arahlk 1923).

84. BCA. No: 051/7.64.82, 26 Nisan 1339 (26 Nisan 1923). 
gönderilen bir yazıda şu ifadelere yer verilmektedir: "Medâris kanununun 2. maddesi mûcibince Darü'l-Hilâfe Medreseleri medâris-i ilmiyenin ıslah edilmiş olan şekl-i mütekamilidir. Bu teşkilat yapılan mahallerde bulunan medâris, tedricen bu nam altında tevhid ve hepsi aynı gayeye doğru tevcih edilecektir. Binaenaleyh Darü'l-Hilâfe medresesi talebesinin beytûtetine veyahut sınıf ittihazına elverişli olanlardan Darü'l-Hilâfe müdürlerinin münasip gördükleri medreselerin Darü'l-Hilâfe talebesine tahsis edilmesi ve bu suretle yâr ü ağyâra karşı medresenin mevkiinin yükseltilmesi hususlannda medrese-i mezkûre müdürlerine icabeden nasr ve her türlü muavenet-i maddîye ve manevîyenin ibraz olunması kemal-i ehemmiyetle tavsiye olunur". 85

Elde ettiğimiz bilgilere bakıldığında nizamnamenin hazırlandığı 8 Mayıs 1921 tarihinden iki yıl geçmesine rağmen mevcut medreselerin nizamname şartlarına uygun hale getirilmesinde yeterli başarının sağlanamadığı, yeni medreselerin ancak 1922 yılı başlarında açılmaya başlandığı, açılan medrese sayısının yanısıra, oluşturulabilen sınıf ve kaydedilen talebe sayısının da çok yetersiz kaldığı görülmektedir.

\section{Ders Programlarinin Uygulanmasl ve Imtihanlar}

Nizamnamenin hazırlandığı dönemde daha önceki ıslahat kapsamına giremeyen medreselerde geleneksel medrese programının devam ettiği anlaşılmaktadır. Nitekim, Izmit Müftülügüu'ne verilen bilgide Kandıra'da halen açık medrese bulunmadığı, seferberlikten önce ise açık olan medresenin üç sınıfa bölündüğü, ilk sınıfta Şerh-i Akaid ve Şifa-i Şerif, ikinci sınıfta Mantık, üçüncü sınıfta ise Nahiv öğretiminin yapıldığı belirtilmektedir. ${ }^{86}$ Yine Adapazarı'ndaki Karaosmanağa Medresesi'nde yeni programın uygulanmaya başlanmasından önce Kelam, Sarf, Ulûm-ı Diniye ve Kelam dersleri okutulmaktadır. ${ }^{87}$

Nizamnamenin yürürlüğe girmesinden sonra yeni öğretime başlayan medreselerde uygulanan programlara bakıldığında ilk dikkati çeken husus, medreselerin tamamında bütün sınıfların oluşturulamadığı gerçeğidir. Bu durum, programın da ancak açılabilen sinıflarda uygulandığı sonucunu doğurmaktadır. Adapazarı'nda daha sonra başlatılan yeni tedrisatla medreseye kabul edilen talebeler ikinci sınıftan başlatılmış; ancak programda bazı değişikliğe gidilmiştir. Nizamnamede bu sınıfta Avâmil ve İzhar dersleri olmasına rağmen bu yıl Sarf okutulması, yine Halebî yerine

85. BCA. No: 051/5.43.3, 26 Agustos 1339/13 Muharrem 1342 (26 Agustos 1923).

86. BCA. No: 051/7.63.7, 10 Kanunusânî 1338/11 Cemaziyelâhir 1340 (10 Ocak 1922)

87. BCA. No: 051/7.63.6, 5 Kanunusânî 1338/6 Cemaziyelevvel 1340 (5 Ocak 1922). 
hem Kıraat ve Imla derslerine destek olması hem de dinî bilgilerini temin için talebelere Türkçe ilmihal kitabı okutulması tercih edilmiştir. Konuyla ilgili belgede, programda yer verilen Arabî dersi ile neyin kasdedildiğinin anlaşılamadığı ifade edilmektedir. Diğer taraftan medresenin açılmasının yıl ortasına rastlaması ve derslerin tam göruilememesi nedeniyle talebelere bu sınıftaki derslerin gelecek yıl tekrar okutulacağ 1 da ifade edilmektedir. ${ }^{88}$ Nitekim daha sonra aynı konuyla ilgili yazılan diğer bir yazıda medresenin açılmasından yaklaşı birbuçuk ay sonra Ramazan tatiline girildiği, ardından tekrar derslere başlanmış ise de bu yıl yeterli süre ders yapılamadı̆̆ından, imtihan talimatının 7. maddesi gerekçe gösterilerek talebelerin sınıflarında bırakılıp 15 Haziran 1922 tarihinde medresenin tatil edildiği bildirilmektedir. ${ }^{89}$ Programın Kayseri'deki uygulamasında da ikinci sınıftaki Arabî dersinin Kıraat-ı Arabiye şeklinde anlaşıldı̆̆ 1 görülmektedir. ${ }^{90}$ Bu bilgiler, programın uygulama esnasında bazı değişikliklere uğrayabildiği; ayrıca programda bazı kapalı noktaların olduğunu da ortaya koymaktadır.

Benzer bir durumun Köyceğiz ve Bodrum'da da söz konusu olduğu, Köyceğiz'de açılan medresede ilk iki sınıfın bulunduğu ve nizamnamedeki bu sınıflarla ilgili programa tam olarak uyulduğu, 2. sınıf programındaki Arabî dersinde ise Mükâleme-i Arabî dersinin okutulduğu, ${ }^{11}$ buna karşıllk Bodrum'daki medresenin 2. sınıf programında ise aynı derste İzzînnin okutulduğu görülmektedir. ${ }^{92}$ Konuyla ilgili belgede yer verilen imtihan programından, açılan medresenin ilk üç sınıfında öğretim yapıldığı ve nizamnamedeki öğretim programına tam olarak uyulduğu; ancak imtihanlar için hazırlanan talimatın 2. maddesinde imtihanların Haziran ya da Mayısta yapılacağı belirtilmesine rağmen Nisan ayında yapıldığı, nedeni hakkında da bilgi verilmediği görülmektedir. Benzer duruma Gümüşhacıköy'de de rastlanmaktadır. ${ }^{93}$ Esasen nizamnamenin 25. maddesine göre Ramazan ayı tatil olarak belirlenmiş ise de bu aydan sonra derslere devam edilmesi de gerekmektedir. Sözü edilen imtihanların erken tarihe alınmasından Şer'iye Vekaleti'nin de haberdar olduğu, Vekâlet'in bu seneye mahsus olmak üzere imtihanların Ramazan'dan bir hafta önce başlatılarak daha sonra talebe ve muallimlere izin verilmesi isteğinin yer aldığı belgeden anlaşılmaktadır. ${ }^{94}$

88. BCA. No: 051/7.63.26, 26 Mart 1338 (26 Mart 1922).

89. BCA. No: 051/7.63.35, 31 Mayis 1338/4 Sevval 1340 (31 Mayıs 1922); BCA. No: $051 / 7.63 .45,25$ Haziran 1338 (25 Haziran 1922).

90. Nesimi Yazıcı, "Kayseri Medâris-i İlmiye Karar Defteri Üzerine Bazı Düşünceler", II. Kayseri ve Yöresi Tarih Sempozyumu Bildirileri, Kayseri 1998, s. 468. Kayseri'de medresenin sekiz sınıf ile öğretime devam ettiği anlaşılmaktadır.

91. BCA. No: 051/13.113.70, 31 Kanunuevvel 1338 (31 Aralık 1922).

92. BCA. No: 051/13.113.34, 1 Nisan 1338/21 Şaban 1340 (I Nisan 1922)

93. BCA. No: 051/2.1.4, 16 Nisan 1338 (16 Nisan 1922.

94. BCA. No: 051/13.113.22, 15 Mart 1338 (15 Nisan 1922). 
Hendek Müftülüğü'nden verilen bilgiye göre ise birinci ve ikinci sınıflarda öğrenim gören toplam 19 talebenin imtihanlan yapılmış ve talebelerin tamamı sınıflarında bırakılmışlardır.95 Belgede, talebelerin hepsinin sınıflarında bırakılmalarına temas edilmemekle birlikte burada da daha önce Adapazan için bahsettiğimiz, öğretime geç başlanması ve derslerin tamamlanamamış olmasının gerekçe gösterilerek böyle bir yola gidilmiş olması mümkündür.

1922 yılı sona erip ertesi öğretim yılının başlamasının yaklaştı̆̆ı sırada karşılaşılan önemli problemlerden birisi de okutulacak derslerin müfredatının ve hangi kitapların okutulacağının belirlenmemiş olmasıdır. Adapazarı Müftülüğü'nden İzmit Müftülüğü'ne yazılan bir yazıda bu önemli konuya temas edilerek şu sözlere yer verilmektedir: "Sene-i tedrisiye ibtidası takarrüb etmekte ve halbuki okunacak derslerin müfredat programı henüz tebliğ buyrulmamış olmakla mesela Hesap'tan her sınıfta okutulacak mebâhis ve Kıraat'tan hangi müellifin kitabı intihab olunacağı meçhul bulunmakta olduğundan sene-i tedrisiye hulûlünde müşkilat çekilmemek üzere şimdiden tayin buyurulması rica ve istirham olunur...".96 Bununla birlikte, yaptığımız araştırmalar sırasında ilmiye medreselerinde okutulacak derslerle ilgili müfredat çalışmasına rastlamadığımızı belirtmeliyiz.

Öğretim yılı sonunda yapılması kararlaştırılan genel imtihanların 1923 yılında, nizamnamede belirtilen tarihte yapıldığı belgelerden anlaşılmaktadır. Gümüşhacıköy Müftülüğu'ne Şer'iye Vekaleti'nden gönderilen yazıda, imtihanlarda son derece titiz davramılması istenilerek sonuçların kaydedildiğ $i$ cetvellerin her sınıftaki talebelerin derslerden aldıkları notlara göre düzenlenmesi, aynca talebelerin doğum tarihleri, medresenin adı, nereye bağlı olduğu, açılış onayı ve tarihi ile ilgili bilgilerin de eklenerek sonuçların merkez ve kazalardaki Encümen-i İlmî'lere bildirilmesi istenmiş, ${ }^{97}$ talep daha sonra aynı yılın Haziran ayında tekrarlanmıştır.98 1923 yılına ait bu iki belgeye bakıldığında imtihanların nizamnamede öngörüldüğü tarihte yapıldıkları anlaşılmaktadır. Nitekim Gümüşhacıköy'den gönderilen yıl sonu genel imtihan cetveli Haziran ayı sonunda hazırlanmıştır. ${ }^{99}$ Cetvelde yer verilen bilgilere göre medresede toplam 38 talebe öğretim görmektedir. Bunlardan üçü birinci sınıf talebesi olup sınıfta kalmışlardır. İkinci sınıfta ise

95. BCA. No: 051/7.64.12,18 Ağustos 1338 (18 Ağustos 1922). Hendek'de yeni usule geçilmeden önce ise Sarf, Nahiv, Hadis ve Fıkıh dersleri okutulmaktadır. Bk. BCA. No: 051/7.63.8, 13 Kanunusâni 1338/14 Cemaziyelevvel 1340 (13 Ocak 1922).

96. BCA. No: 051/7.64.11, 16 Agustos 1338/21 Zilhicce 1340, (16 Ağustos 1922).

97. BCA. No: 051/2.1.19, 27 Mayıs 1339 (27 Mayıs 1923).

98. BCA. No: 051/2.1.24, 20 Haziran 1339/15 Zilkade 1341 (20 Haziran 1923).

99. BCA. No: 051/2.1.22, 26 Haziran 1339 (26 Haziran 1923) 
25 talebeden 17'si sınıflarını geçmişler, beşi kalmış üçü de imtihana gelmemiştir. Üçüncü sınıftaki yedi, dördüncü sınıftaki üç talebenin tamamı başanılı olarak bir üst sınıfa geçmişlerdir.

Benzer şekilde, Kocaeli Müftülüğü'ne bağlı bölgelerden Adapazan, Hendek ve Geyve'den gelen yazılardan 1923 yllındaki imtihanların Haziran ayında tamamlandığı anlaşılmaktadır. Adapazarı'da bu yıl sadece ikinci sınıfın mevcut olduğu ve sayısı belirtilmeyen talebelerin tamamının sınıflarını geçtikleri bildirilmektedir. Hendek'de 1. ve 2. sınıfların imtihanlarının tamamlandığı ve sonuçlarla ilgili cetvelin gönderildiği bildirilmekte ancak sonuç hakkında bilgi verilmemektedir. Geyve'den gönderilen yazıda da sekiz talebesi olan birinci sınıftaki talebelerin derslere düzenli devam etmedikleri ve yetersiz olduklan için tamamının sınıfta bırakıldıklan, ikinci sınıf talebelerinin imtihan sonuçlarının ise cetvel halinde gönderildiği belirtilmekte; ancak bu talebelerin sayıları ve başanı durumları hakkında bilgi verilmemektedir. ${ }^{100}$

İlmiye medreselerindeki programın uygulanışı ile ilgili olarak elde ettiğimiz belgeler arasında 1923-1924 öğretim yılına ait bir haftalık ders programı bulunmaktadır. ${ }^{101}$ Fatsa'daki ilmiye medresesinin üçüncü sınıfına ait, esasen yoklama defteri olarak kullanılan ve $3 \mathrm{~T}$. Evvel 1339/13 Mart 1340 (3 Ekim 1923/13 Mart 1924) tarihleri arasinda tutulan bu defterde, mevcut 23 talebenin isim ve numaralan ile günlük yoklama kayıtlarının yanısıra her derste işlenen konulara dair bilgiler de bulunmaktadır. Günümüzde okullarda kullanılan ve öğretmenlerin işledikleri derslerle ilgili bilgilerin bulunduğu defterlere benzeyen bu defterden haftalık ders programını çıkartmamız mümkün olmaktadır:

$\begin{array}{llll}\text { Günler } & \underline{\text { 1. Ders }} & \text { 2. Ders } & \underline{\text { 3. Ders }} \\ \text { Cumartesi } & \text { Nahv-i Arabî (Câmî) } & \text { Coğrafya } & \text { Halebî } \\ \text { Pazar } & \text { Nahv-i Arabî (Câmî) } & \text { Hesap } & \text { Kavaid-i Türkiye } \\ \text { Pazartesi } & \text { Kıraat-ı Arabî } & \text { Kavaid-i Türkiye } & \text { Cợrafya } \\ \text { Salı } & \text { Nahv-i Arabî (Câmî) } & \text { Merah } & \text { Halebî } \\ \text { Carşamba } & \text { Nahv-i Arabî (Câmî) } & \text { Merah } & \text { Halebî } \\ \text { Perşembe } & \text { Nahv-i Arabî (Câmî) } & \text { Hesap } & \text { Halebî̀ }\end{array}$

100. BCA. No: 051/8.65.3, 24 Haziran 1339 (24 Haziran 1923).

101. BCA. No: 051/1.20.20. Programın, Kayseri'de de uygulanmaya başladığı 8. sınıfa kadarki dersleri okutmak üzere yapılan görevlendirmeden anlaşılmaktadır; ancak zikredilen belgeden derslerin haftalık programının yapılmadı̨̆ anlaşılmaktadır. Bk. Esma Çelik, Tevhid-i Tedrisat Kanununa Kadar Türkiye'de Medreseler, Ankara Üniversitesi Sosyal Bilimler Enstitüsü, Basılmamış Yüksek Lisans Tezi, Ankara 2000, s. 99-102. 
Benzer bir program 1. ve 2. sınıflar için Köyceğiz medresesi için hazırlanmıştır. ${ }^{102}$

\begin{tabular}{|c|c|c|c|c|}
\hline & 1. Sinif & & 2. Sinif & \\
\hline & Sabah & Ögle & $\overline{\text { Sabah }}$ & Ögle \\
\hline & Sarf & - & İmla-Kıraat & - \\
\hline Cumartesi & İmla ve Kıraat & - & - & Halebî \\
\hline & Lügat-i Arabiye & - & - & Hesap \\
\hline & & & - & Hat \\
\hline Pazar & K. Kerim & - & Avâmil ve Izhar & - \\
\hline & - & Hesap & Mükaleme-i Arabî & - \\
\hline & - & Hat & Lügat-i Arabî & - \\
\hline Pazartesi & Sarf & - & Avâmil ve İzhar & - \\
\hline & K. Kerim & - & - & Halebî \\
\hline & Lügat-i Arabiye & - & - & Lưgat-i Arabî \\
\hline Salı & Sarf & - & - & Avâmil-Izhar \\
\hline & Lügat-i Arabiye & - & & \\
\hline Çarşamba & Sarf & - & Avâmil ve İzhar & - \\
\hline & İmla ve Kıraat & - & - & Imla ve Kiraat \\
\hline & K. Kerim & - & - & Halebî \\
\hline & - & Hesap & - & Hesap \\
\hline & - & Hat & - & Hat \\
\hline Perşembe & Sarf & - & - & Avâmil-İzhar \\
\hline & K. Kerim & - & - & Halebî \\
\hline
\end{tabular}

Yeni açılan medreselerde programın uygulaması ile ilgili olarak dikkati çeken ve eksikliği hissedilen en önemli konu belirlenen derslerin müfredatının hazırlanmamı̧ olmasıdır. Böyle bir çalışmanın, bütün medreselerde ortak bir öğretimin yapılabilmesi ve uyumun sağlanabilmesi için faydalı olacağı açıktır. Nitekim yukarıda da bahsettiğimiz gibi bazı derslerde nelerin okutulması gerektiği hususunda tereddütler yaşanmış ve farklı uygulamalara gidilmiştir. Diğer taraftan müfredatla birlikte okutulacak ders kitaplarının da belirlenmesi aynı amaçlar için gereklilik arzetmektedir. Dârü'l-Hilâfe medreseleri için yapıldığını bildiğimiz böyle bir çalışmanın ilmiye medreseleri için yapılmamış olmasını, Dârü'l-Hilâfe medreselerinin örnek medrese modeli olarak kabul edilip bu medreselerin şimdilik ve geçici olarak düzenlenmesi düşüncesine bağlamạk yanlış olmayacaktır.

\section{Müderris İhtiyacının Karşılanması ve Mâli İmkanlar}

Hazırlanan programda yer verilen dersleri okutacak müderris ve muallimlerin gerek temininde gerekse görevlendirilmelerinde önemli 
zorluklarla karşılaşıldığı, bunun başlıca nedenin görevlendirilecek elemanlara ücr̈et ödenememesi olduğu görülmektedir.. ${ }^{103}$ Bununla birlikte yeterli sayı ve nitelikte müderris ve muallimin bulunabilmesi de zorluğun diğer tarafını oluşturmaktadır. Medrese öğretiminin geleneksel alan derslerini oluşturan din bilimleri ve Arapça derslerini okutacak müderrisler kimi zaman maaşsız olarak bile bu görevi kabul edebilmekte; ancak bunların dışındaki dersleri okutacak muallimlerin tedarik edilmesi ciddî bir problem olarak ortaya çıkmaktadır.

Tesbit ettiğimiz belgeler mâlî imkansızlıklar yüzünden muallim ve müderris bulunmasında zorluklarla karşılaş̧ıldığını açıç̧a ortaya koymaktadır. Nitekim bu konuya temas edilen bir belgede Adapazarı'ndaki Karaosmanağa Medresesi'nde yeni programın uygulanmasına henüz başlanmadı̆̆ı, başlandığı zaman Kur'an, Arapça, Farsça ve Ulûm-ı Diniye dersleri dışındaki derslerin okutulması için dışarıdan muallimler tedarikinin zarurî olacağı, bu hizmeti karşılıksız yapanlardan eğitim-öğretimde yeterince yararlanılamadı̆̆ı için mutlaka maaş ödenmesi gerektiği, buna karşılık Adapazarı'nda her ikisi de dolu olan maaşlı sadece iki müderris kadrosu bulunduğu belirtilmektedir.104 Yine Adapazarı Müftülüğü'nden bundan yaklaş̧k bir ay sonra İzmit Müftülüğü'ne yazılan başka bir yazıda, yeni nizamnamenin kendilerine ulaştığı belirtilmekte ve nizamnamede öngörülen programın uygulanmasında muallim sıkıntısı duyulacağı dile getirilerek çözüm teklif edilmektedir. Buna göre, Izmit Liva Meclis-i Umumisine, liva içinde açılmış medreselerin her birisine bir muallim tahsisatının konulmasının teklif edilecek, şayet kabul edilirse bu kadroya alınacak bir Türkçe muallimi ile programın uygulanmasında önemli bir kolaylık sağlanabilecektir. ${ }^{105}$ Yapılan bu teşebbüsün başlangıçta neticesiz kaldığı yine Adapazarı Müftülüğü'nün Ocak 1923 tarihli bir yazısından anlaşılmaktadır. ${ }^{106}$ Belgede, tekrar muallim konusundaki sıkıntı ve bu yüzden programın yeterince uygulanamadığına dikkat çekilerek Arapça derslerinin imkanlar ölçüsünde devam ettiği; ancak Türkçe dersleri için muallim bulunamadığı, mekteplerden temin edilen fahrî muallimlerden ise beklenen

103. Şer'iye Vekaleti TBMM'de o yıllarda yapılan bütçe görüşmelerinde medreselerde görevli müderris ve muallimlerin ckonomik durumlarının iyileştirilmesi meselesini gündeme getirmiş; ancak imkansızlıklar yüzünden sonuç elde edilememiştir. Bk. Veli Öztürk, Türkiye'de Din Eğitimi ve Siyaset (TBMM Zabıtlarında Din Eğitimi Tarış̧maları 1920-1990), Basılmamış Doktora Tezi, Dokuzeylül Üniversitesi Sosyal Bilimler Enstitüsü, İzmir 1997, s. 132 vd.

104. BCA. No: 051/7.63.6, 5 Kanunusânî 1338/6 Cemaziyelevvel 1340 (5 Ocak 1922).

105. BCA. No: 051/7.63.19. 19 Şubat 1338/20 Cemaziyelâhir 1340 (19 Şubat 1922).

106. BCA. No: 051/7.64.61, 24 Kanunusânî 1339 (24 Ocak 1923). 
verimin elde edilemediği belirtilmektedir. Yazıda, yukarıda sözünü ettiğimiz geçen yıla ait taleplerinin yerinde bulunmadığı; ancak diğer bazı yerlerde mahallî bütçelerden müderris tahsisatının alınmasının başarıldığının bilindiği için bu talebin tekrarlanmasının yerinde olacağı belirtilmektedir. Medreselerin de mektepler gibi eğitim kurumlan olduğu ve memleketin eğitim alanındaki ilerlemesine önemli katkılarının bulunduğundan söz edilerek Kocaeli müftüsünden Meclis-i Umumî-i Liva nezdinde gerekli girişimde bulunarak medreselerdeki Türkçe öğretmenleri için 1339-1340 senesi bütçesine tahsisat ayrılmasını sağlaması istenmektedir. Belgeden, ücret almadan ders veren muallimlerden yeterli verimin alınamadığı; ancak mesaisinin tamamını medresedeki derslere ayıracak maaşlı muallimlerin temininin ödenek bulunmaması yüzünden mümkün olamadığı, özellikle klâsik medrese öğretimi dışında kalan derslerde sıkıntı olduğu ve tahsisatın mahallî kaynaklardan karşılanması yolunun denendiği açıkça anlaşılmaktadır.

Benzer bir talep yine Kocaeli Müftülüğü'ne Kandıra'dan gelmektedir. ${ }^{107}$ Konuya yer verilen belgede, Kandıra'daki medresenin faaliyete geçebilmesi için gerekli olan ilmî encümeni oluşturacak kimselerin bulunmasında güçlük çekildiği, bu görevi yapabilecek olanlann da fahrî hizmeti kabul etmedikleri belirtilerek tahsisatsızlıktan şikayet edilmektedir. Anadolu'da bazı vilayetlerde hususî bütçeden müderris tahsisatı ayrılmasına rağmen bunun yaygınlaştırılmadığından şikayet edilmekte, Kocaeli Sancağı için bunun sağlanması ve Kandıra'da kurulacak medrese için de bir müderris tahsisatı gerektiği dile getirilmektedir. Son iki belgede medreselerin ülkenin eğitimi ve yetiştirdikleri kişilerden bahsedilerek kendilerine gerekli ilginin gösterilmediği ihsas ettirilmekte ve ilgi beklenmektedir. Kocaeli Müftülügüu'nün kendisine bağlı bölgelerden gelen mahallî bütçeden tahsisat talebi karşısındaki yoğun istekler karşısında durumu Ankara'ya bildirerek medreselerin tahsisat olmadan idaresinin güçlüğünden bahsettiği, Vekalet' in uygun görmesi halinde hususî idareden tahsisat talebinde bulunmak istediği belirtilerek bu konuda nasıl bir yol takip edilmesi gerektiği konusunda görüş sorulmaktadır. ${ }^{108}$

Yine diğer bir belgede, Adapazarı'nda faaliyete geçen ilmiye medresesinde Hesap, Imla, Kıraat ve Hat derslerinin bazı mektep muallimleri tarafından verildiği; ancak müderris ve muallimlerin tahsisatı olmadığı için beklenen ölçüde verimin alınmasının mümkün olmadı̆̆ı zikredilmektedir. ${ }^{109}$

107. BCA. No: 051/7.64.60, 20 Kanunusânî 1339/2 Cemaziyelâhir 1341 (20 Ocak 1923).

108. BCA. No: 051/7.64.71, 14 Mart 1339 (14 Mart 1923).

109. BCA. No: 051/7.63.26, 26 Mart 1338 (26 Mart 1922). 
Kocaeli Müftülüğü'nün yaptığı girişimlerin netice verdiği sonraki yazışmalardan anlaşılmaktadır. Aralık 1923 tarihli bir belgede İzmit, Adapazan, Geyve ve Hendek ilmiye medreselerinin her birisine aylık 2000 kuruş tahsisat ile birlikte Türkçe ve fünûn derslerini okutmak üzere birer muallim tayin edildiği, gerekli meblağın 1923 (1339) yılı Eylül ayından itibaren Kocaeli Vilayeti Hususî İdare bütçesine Maarif Vekâleti tarafından konulacağı, tayin edilen muallimlerin Ekim ayından itibaren görevlerine başladıklan bildirilmektedir. ${ }^{110}$ Bulunan kaynakla sıkıntı şimdilik giderilmiş olmakla birlikte söz konusu yerlerden gönderilen yazılarda, bu yıl medreselerde üçer sınıfın bulunduğu ve 1923-1924 öğretim yılı sonunda dördüncü sınıfın açılacağı dikkate alındığında bu ödeneğin artırılarak devam ettirilmesi gerektiği ifade edilmektedir;"111 zira aylık 2000 kuruş, iptidaî (ilkokul) muallimlerinin asgarî maaşlarından bile daha az olduğundan medrese muallimliğine ilgi gösterilmemektedir. Bu itibarla tahsisatın 1924 yılında artırılması gerektiği ifade edilerek bütçe için şu teklif getirilmektedir: ${ }^{112}$

Tahsisatın Türü

Izmit Medâris-i Ilımiyesi

Adapazan

Geyve

Hendek
1923 Yılı Tahsisatı(Kr.) 1924Yıłı İçin Teklif Edilen Tahsisat(Kr.)

12.000

12.000

12.000

12.000

48.000
36.000

36.000

36.000

36.000

144.000

Şer'iye Vekaleti içinde bulunulan maddî sıkıntılara rağmen müderrislere maaş tahsisi hususunda elinden gelen gayreti sarfetmektedir. Muğla Müftülüğü'ne gönderilen bir yazıda Muğla, Milas, Foça, Köyceğiz ve

110. Geyve, Hendek ve Adapazar Müftülükleri'nden gönderilen yazılar bu bilgiyi dogrulamaktadır. Adapazarı Müftülügư'nün yazısında bildirildiğine göre söz konusu aylık 2000 kuruş kendilerine intikal etmiş ve medresedeki Türkçe muallimliğine Adapazanı Idadisi Tarih ve Coğrafya muallimi İsmail Hakkı Bey getirilmiştir. Bk. BCA. No: 051/8.65.33, 16 Teşrinievvel 1339 (16 Ekim 1923). Geyve Müftülü̉̆ü’nün yazısında da söz konusu tahsisatla Türkçe muallimliğine idadi mektebi mezunu Geyve Kadısı Hikmet Efendi'nin getirildigi belirtilmektedir. Bk. BCA. No: 051/8.65.45, 15 Kanunuevvel 1339 (15 Aralık 1923). Hendek Müftülüğü ise Türkçe muallimliğine Kadı Ibrahim Hakkı Efendi'nin atandığını bildirmektedir. Bk. BCA. No: 051/8.65.43, 11 Kanunuevvel 1339 (11 Aralık 1923).

111. Bu ihtiyaç, yukarıda bahsettiğimiz Geyve, Hendek ve Adapazarı Müftülükleri'nin yazılarında da özellikle vurgulanmaktadır. Sadece Kandıra Müftülüğü, 1923 yılında açılan medreselerinde bu yıl birinci sınıfın bulundugunu ve Türkçe muallimine, üçüncủ sınıfın oluşacă̆ı 1925 yılına kadar ihtiyaçlarının olmadığını belirtmektedir. Bk. BCA. No: 051/8.65.44, 11 Kanunuevvel 1339 (11 Aralık 1923).

112. BCA. No: 051/8.65.46, 16 Kanunuevvel 1339 (16 Aralık 1923) 
Bodrum merkezlerine ikişeryüz kuruş maaşla birer müderris tayin olunacağından bu kadrolarda, ilmiye medreselerinde görev yapıp tahsisatları bütçeden kaldırılan, şayet yok ise ilmî yeterliliği imtihanla belirlenecek müderrislerin görevlendirilmeleri istenmektedir.113 Yine Vekalet'ten Gümüşhacıköy Müftülüğ̈̈'ne yazılan yazıda ilmiye medresesinde 200 kuruş maaşla görev yapan Türkçe ve Riyaziye mualliminin maaşının 500, müderrisin maaşının ise 400 kuruşa yükseltildiği ifade edilmektedir. ${ }^{114}$ Bununla birlikte daha sonraki yıllarda yeni açılan medreselerde görevlendirilecek müderrislere maaş ödenmesinde güçlüklerle karşılaşıldığ1 görülmektedir. Nitekim Vekalet'ten 1923 yılı başında gönderilen bir yazıda Gümüşhacıköy'ün Gümüş nahiyesinde bir medresenin açılışının onaylandığ 1 bildirilmekte ve bu medresede dersleri fahrî olarak okutacak Hey'et-i Tedrisiye'nin bulunup bulunmadığı sorularak şayet bulunuyorsa bu müderris ve muallimlerin isimleri ile medresedeki talebelerin miktarı, sınıfları ve doğum tarihlerini belirten bir cetvelin gönderilmesi istenmektedir. ${ }^{115}$ Anlaşıldığı kadarı ile bu medresede şayet fahrî eleman bulunmaz ise Vekalet maaşlı kadro gönderemeyecek durumdadır.

Görevlendirilecek muallim ve müderrislerin Vekalet tarafından onaylanmaları gerekmektedir. Nitekim Vekalet'ten Gümüşhacıköy Müftülügüune yazılan yazıda ulemadan ve Darülmuallimin mezunlarından iki kişinin medresede görevlendirilmeleri talebi kabul edilmiştir. ${ }^{116}$

Çoğu medreseye yeni teşkilatın kurulmasından sonra bile ancak tek müderris maaşla atanabilmiş, memurluk ve hademeler için ise tahsisat bulunamamıştır. Nitekim Geyve'deki medreseye Vekalet'in tüm gayretlerine rağmen uygulama bu şekilde olmuştur. ${ }^{117}$

Hendek'de faaliyete geçen ve 1., 2., 5. ve 11. sınıfların oluşturulacağ 1 tahmin edilen medresede öğretim için dört kişi belirlenmiştir ki bunlar arasında bir müderris, bir imam ve kaza müftüsü bulunmaktadır. ${ }^{118}$ Öğretimin yapılacağı sınıflar ile muallim veya müderris sayısı karşılaştırıldığında arada bir dengesizlik ve yetersizlik bulunduğu açıkça görülmektedir.

Medreselerde görevlendirilecek ilmî yeterliliğe sahip müderrislerin bulunmasında da zorluklarla karşılaşılabilmektedir. Köyceğiz Müftülüğü tarafından yazılan bir yazıda mevcut medresede görevlendirilmek üzere ihtiyaç duyulan müderris için ilan verildiği ayrıca araştırıldığı halde bu

113. BCA. No: 051/13.113.1, 1 Kanunusânî 1338 (1 Ocak 1922)

114. BCA. No: 051/2.1.11, 24 Eylül 1338 (24 Eylül 1922).

115. BCA. No: 051/2.1.15, 13 Kanunusânî 1339 (13 Ocak 1923).

116. BCA. No: 051/2.1.2, 21 Şubat 1338 (21 Şubat 1922).

117. BCA. No: 051/7.63.11, 23 Kanunusânî 1338 ( 23 Ocak 1922).

118. BCA. No: 051/7.65.25, 17 Mart 1338/18 Receb 1340 (17 Mart 1922) 
görevi yerine getirebilecek yeterlilikte kimsenin bulunamadığı ifade edilmektedir; 119 ancak Köyceğiz'deki ilmiye medresesi ile ilgili bu tarihten daha önceye ait bir belgeden medresede müftü, tahrirat katibi ve iki kadının görev yaptıklan görülmektedir. ${ }^{120}$ Bu bilgilerden, medresede ehil öğretim elemanı bulunamadığından dolayı öğretimin asıl görevleri müderrislik veya muallimlik olmayan kişilerce yürütüldüğü anlaşılmaktadır.

Diğer taraftan ihtiyaç duyulan öğretim elemanlarının temininde mekteplerde görevli muallimlerden faydalanıldı ğı, maaşların ödenmesinde de halkın yardımlanına başvurulduğu görülmektedir. 1923 yılı başlanına ait bir belgede, Karasu'ya bağlı Koca Ali köyünde halkın yardımlanı ile yaptırılan iki hücreli medresenin faaliyete geçtiği, müderrise ödenecek 250 kuruş aylığın temininde nahiye muhtarlarının taahhütte bulundukları; ayrıca medresenin yanıbaşında bulunan mektebin mualliminin Türkçe derslerinin okutulmasında yardımcı olacağı ifade edilerek onay talep edilmekte, daha sonraki yazı ile de Türkçe dersleri için üç fahrî muallimin tedarik edildiği belirtilmekte ve açılış onay talebi tekrarlanmaktadır. ${ }^{121}$

Söz konusu maddî sıkıntıların medrese talebeleri için de geçerli olduğu görülmektedir. Talebelerin özellikle son dönemlerde önemli bir gelir kaynağı halini alan cerr usulünün bu yıllarda da devam ettiği anlaşılmaktadır. Şer'iye Vekaleti'nden Mut'a gönderilen bir yazıda, Ramazan dolayısıyla taşraya gidecek talebe-i ulûmun ellerinde talebe olduklarına dair belgelerin yeterli kabul edilerek kendilerine kolaylık gösterilmesi istenmektedir. ${ }^{122} \mathrm{Yaz}$ tatillerinde memleketlerine gidip gelecek medrese talebelerinin trenle yapacakları seyahatlerinde bazı kolaylıklar sağlanmaktadır. Izmit Müftülüğü'ne Vekâlet'ten gönderilen bir yazı ve ekinde Nafia Vekaleti tarafından talebelerin trenlerde talebe olduklarını gösteren belge ile yarı ücret ödeyerek tatil zamanlarında seyahat edebilecekleri konusunda onay alındığı bildirilerek bunun bağlı müftülükler aracılığı ile talebelere bildirilmesi istenmektedir. ${ }^{123}$

\section{Medaris-i Ílmiye Nizamnamesinin Uygulanmasında Elde Edilen} Başarı

Planlaması yapılan bu çalışmanın uygulamadaki başarısı ve elde edilen sonuca bakıldığında istenen sonuca ulaşıldığını söylemek mümkün görün-

119. BCA. No: 051/13.113.26, 5 Şubat 1338 (5 Şubat 1922).

120. BCA. No: 051/13.113.70, 31 Kanunuevvel 1338 (31 Aralık 1922).

121. BCA. No: 051/7.64.53, 6 Kanunusânî 1339 (6 Ocak 1923); BCA. No: 051/7.64.67, 19 Şubat 1339 (19 Şubat 1923).

122. BCA. No: 051/4.36.5, 31 Mart 1339 (31 Mart 1923).

123. BCA. No: 051/8.65.9, 22 Zilkade 1341 (6 Temmuz 1923) 
memektedir. Böyle bir kanaate varmamızdaki nedenlerden ilki yukarıda, nizamnamenin uygulanması ile ilgili yaptığımız tesbitlerdir. Bu hususta elde edebildiğimiz bilgilere göre yeni medreselerin açılmasında ve programın uygulanmasında gerekli öğretim için gerekli elemanların temini, yeterli talebe sayısı ve mâlî kaynakların oluşturulması gibi konularda çok ciddî problemlerle karşıllaşılmış, açılabilen medreselerin neredeyse tamamında sadece birkaç sınıfla öğretime başlanabilmiştir.

İkincisi ise dönemin Şer'iye Vekili tarafından hazırlanan ve başlatılan hareketin seyri, problemleri ve başarı derecesi hakkında bir kanaate ulaşılmasını sağlayacak açık bilgi ve değerlendirmelere yer verilen genelge(tamim)dir. ${ }^{124}$ Özellikle müftülerin ilgisizliğinden şikayet edilerek buna bağlı olarak ortaya çıktığı düşünülen ekonomik sebepler yüzünden başlatılan hareketin beklenen başarıyı gösteremediği dile getirilen belgede, TBMM tarafindan hazırlanan nizamnamenin yayınlanmasından sonra bazı müftülerin medreselerin açılması ve yaşatılması yönünde önemli çabalar sarfettikleri belirtilerek Erzurum ve Yozgat Müftülerinin çalışmalarından övgü ile söz edilmektedir. Buna karşlık diğer bazılarının esasen memlekette boş ve kullanılmayan birçok medrese olduğu, halkın da medreselere büyük bir sevgi ve bağlllıklan olduğu halde konunun sahip olduğu önemi kavrayamayarak biraz da olsa gayret göstermeyip bir medrese bile açmaya muvaffak olamadıklan, kimi müftülerin de bir medrese açmayı başarmakla birlikte açtığı kurumun yaşatılması ve geliştirilmesi için hiçbir çaba göstermemeleri tenkit edilmektedir. Yazıda mâlî sıkıntıların giderilmesi için iki yol söz konusu edilmektedir ki bunlardan ilki özel idare bütçelerine medreselerin giderleri için ihtiyaç duyulan ödeneğin konulmasının sağlanması diğeri ise kullanılmayan medreselerin vakıf gelirlerinin faaliyete geçirilen medreselere aktarılmasıdır. Erzurum ve Yozgat müftüleri kendi Liva Muvâzene-i Hususiyelerinden (özel idare bütçeleri) medreseler için ödenek aynilmasını başardıklan halde diğerleri bu konuda ciddî teşebbüste bile bulunmamışlardır.

Yazıda, müftülerden bu tamim kendilerine ulaştıktan en çok bir ay süresinde görev alanlan içindeki kasaba, nahiye ve köyler de dâhil olmak üzere ne kadar kullanılamaz durumda medrese olduğu, vakıf gelirlerinin olup-olmadığı şayet varsa miktarı, şu an itibarıyla kullanıma ne derece uygun olduğu, yeni kurulan ilmiye medreselerinin ve talebe sayllan hakkında

124. Umur-1 Şer'iye ve Evkaf Vekili imzası ve "Bütün Müftülere ve Müderrislere Tamim" başlı̆̆ı ile hazırlanan bu belge için, Bk. BCA. No: 051/2.1.13. Belgede tarih bulunmamaktadır; ancak dönemin basınında Kanunuevvel 1338 (Aralık 1922) tarihide yayınlanmışır. Bk. Esma Çelik, Tevhid-i Tedrisat Kanuna Kadar Türkiye'de Medreseler, s. 103. 
bilgileri ihtiva eden ayrıntılı raporu Şer'iye Vekâleti'ne gönderecektir. Yukarıda medreselerin açılmaları hakkında bilgi verdiğimiz başlık altında bu bilgilerin 1922 yıl Kasım ayı başında acele kaydryla istendiğinden bahsetmiştik. ${ }^{125}$ Genelgede tekrar bu konuya kesin bir dille yer verilmesi önceki yazının müftüler tarafından yeterince dikkate alınmadığını göstermektedir. Genelgenin devamında, ülkenin içinde bulunduğu din eğitimi ve öğretimi ile buna duyulan ihtiyaca temasla medreselerin ve ilmiye mensuplarının bu konuda taşıdıkları görev ve sorumluluk özellikle vurgulanarak, birer ilim kaynağı olarak kurulan ve bugüne kadar yaşayan medreselere, asker kaçaklarının değil bu sorumluluğu idrak eden, amacı dine ve vatana hizmet olan kişilerin kabul edilmesi gerektiği belirtilmektedir. Diğer taraftan genelgenin son tarafında, belirtilen hususlara uymadıkları tesbit edilenler hakkında şiddetli cezaların uygulanacağı hatta Istiklal Mahkemesi'ne verilebileceğinin belirtilmesi, bu yönde açık bir bilgiye yer verilmemekle birlikte, medreselere belirlenen kurallar dışında talebe kabul edildiği ihtimalini de akla getirmektedir.

Diğer taraftan şu hususa da temas etmeliyiz ki Tevhid-i Tedrisat Kanunu'nun yürürlüğe girmesi ve medreselerin ilga edilmesinden sonra gerek Maarif Vekili Vasıf Bey tarafından verilen beyanatta gerekse konunun TBMM'nde tartışılması esnasında faal durumdaki 479 ilmiye medresesinin kapatıldığı söz konusu edilmektedir. ${ }^{126}$ Verilen bu bilgi ile yukarıda ortaya koyduğumuz bilgiler karşılaştırıldığında aralannda bir tutarsızlık olduğu görülmektedir; zira söz konusu medrese sayısına bakıldığında genelgede sözü edilen biçimde bir başarısızlığın olmadığı hatta o devrin şartlan içinde ciddî bir başarının elde edildiği sonucuna varmak gerekir. Aksi takdirde ya genelgenin yayınlandığ sayıda medresenin açılmış veya ileri sürülen medrese sayısında bir yanlışlı̆̆ın olması gerekir.

\section{Sonuç}

Kurtuluş Savaşı yıllarında hazırlanan ve savaş yılları ile birlikte Cumhuriyet'in ilanından sonraki dört ay içinde uygulanan Medâris-i İlmiye Nizamnamesi'nin, II. Meşrutiyet döneminden itibaren medreselerin modern eğitim kurumları ile aynı ortamda yaşayabilecek hale getirilme düşüncesi ile başlatılan çalışmaların devamı olduğunu ileri sürmek mümkündür. Bu temel

125. BCA. No: 051/7.64.43.8 Teşrinisânî 1338 ( 8 Kasım 1922).

126. TBMM Zabut Ceridesi, Devre II, İçtima Senesi II, c. 8/1, s. 827, 829, 17 Nisan 1340 (17 Nisan 1924); Hakimiyet-i Milliye, 4. Sene, No: 1070, 6 Şaban 1342/13 Mart 1340 (13 Mart 1924) 
düşünceden hareketle birlikte söz konusu nizamnamenin, hazırlandığı ortam ve şartların sağladığı imkânlar çerçevesinde kendine has çözüm yolu ve uygulanma tarzı bulduğu da görülmektedir. Nitekim nizamname, temelde II. Meşrutiyet'te kurulan Dârü'l-Hilâfe Medresesi'ni örnek medrese tipi olarak kabul etmekle birlikte İlmiye Medreseleri bu örneğe geçiş esnasında hem bir basamak hem de olağanüstü şartların karşı karşıya bıraktığı zorunluluk karşısında geçici bir çözüm yolu olarak sunulmaktadır.

Yapılan bu çalışmaların ülkemizin varlık mücadelesinin devam ettiği son derece hassas bir dönemde gerçekleştirilmesi, din eğitimi ve öğretimine hem teorik ve bilimsel hem de pratik alanlarda duyulan ihtiyacın göz ardı edilmediğinin, aynı zamanda da bu ihtiyaçlara en uygun çözüm yolu arayışlarının somut bir göstergesi olarak kabul edilmelidir. Yapılan çalışmaların değerlendirilmesinin iki noktada toplanması gerekir ki bunlardan birincisi din eğitimi ihtiyacının tesbit edilerek ihtiyacın giderilmesi için gerekli düzenlemelerin yapılması, diğeri de yapılan düzenlemelerin uygulamaya konularak belirlenen hedeflere ulaşılmaya çaba sarfedilmesidir.

Bunlardan planlama ve düzenlemenin yapıldığı ilk aşamada ciddî ve tutarlı tesbit ve çabalar olmasına rağmen ikinci aşama olarak gördüğümüz uygulama aşamasında ortaya çıkan başarısızlığın temelinde şüphesiz yaşanılan olağanüstü şartların varlı̆̆ı ileri sürülebilir; ancak yukarıda sözünü ettiğimiz Şer'iye Vekaleti tarafından hazırlanan genelgeye bakıldığında uygulama esnasında görev alan yetkililerin planlama aşamasındaki çabaların önemini yeterince kavrayamadıkları veya uygulamada gerekli fedakarlık ve beceriyi gösteremedikleri de açıkça görülmektedir. Diğer taraftan Tanzimat'tan bu yana genel idare ve toplumun her kesimi için geçerli kılınmaya çalışılan Batılılaşma sürecinde özellikle eğitim alanında geleneğin temsilcisi medresenin ikinci planda kaldığını unutmamak gerekir. Burada ele aldığımız dönem de dahil olmak üzere ne derece yeterli olduğu ayrı bir tartışma konusu olmakla birlikte II. Meşrutiyet'ten sonraki ıslah çalışmalarının medreselerin varlığını devam ettirebilmeleri için yeterli olmadığı görülmektedir.

Bununla birlikte bir eğitim kurumu için esas önemli olan hususun o kurumun yerine getirdiği fonksiyon ve kendisinden beklenen hedeflere ulaşabilme yeterliliği olduğuna inanıyoruz. Geleneksel yapısı içinde din eğitimi ve öğretiminin medreselerin öğretim amaçları içinde çok fazla ön plana çıkmadığı; ancak son dönem medrese ıslah çalışmalarında amaçlar arasında özellikle birinci planda yer aldığı, böylece medresenin eğitimögretim amacının bu yönde belirlendiği görülmektedir. Bu noktada bizce asıl 
önemli olan husus din eğitimi çalışmalarının özel bir eğitimden geçmiş kişiler tarafından yürütülmesi gerektiği gerçeğinin kabul edilerek ardından medresenin eğitim alanındaki yeni yapılanma içinde gerçek görevine geç de olsa sahip çıkması ve gereğini yerine getirmek üzere harekete geçmiş olmasıdır. Bu aşamadan sonra söz konusu fonksiyonun medrese ya da mektepte gerçekleştirilmesinin öneminin olmadığı, kurumların yapılarının ihtiyaç ve şartlara göre değişebileceği kanaatindeyiz.

Sonuç olarak, hazırlanan Tevhid-i Tedrisat Kanunu'nun 4. maddesinde yer verilen hüküm uyarınca medreselerin din eğitimi-öğretimi ve bu alanda hizmet verecek personelin yetiştirilmesinde fonksiyonunun kalmadı̆̆ gerekçesi ile medreseler ilga edilmişlerdir. Sözü edilen fonksiyonun ihmal edilmemesi kaydıyla böyle bir uygulamanın yanlı̧̧ olduğunu savunmanın tutarlı bir gerekçesinin olduğuna inanmıyoruz. Bununla birlikte söz konusu bu fonksiyonun sonraki yıllarda yerine getirilmesinin ne derece başanlı olduğu konusu ise başka bir araştırma ve tartışma konusu olarak önemini korumaktadır. ${ }^{127}$

\title{
BİBLIYOGRAFYA
}

\author{
Başbakanlık Cumhuriyet Arşivi (Konu No/Belge No). \\ 051/1.20.20. \\ 051/13.113.1, 1 Kanunusânî 1338. \\ 051/2.1.2, 21 Şubat 1338. \\ 051/2.1.4, 16 Nisan 1338 . \\ 051/2.1.11, 24 Eylül 1338 . \\ 051/2.1.13. \\ 051/2.1.15, 13 Kanunusâni 1339. \\ 051/2.1.19, 27 Mayis 1339. \\ 051/2.1.21, 20 Haziran 1339 . \\ 051/2.1.22, 26 Haziran 1339. \\ 051/2.1.24, 20 Haziran 1339/15 Zilkade 1341. \\ 051/3.15.3, 5 Kanunuevvel 1337. \\ 051/4.36.5, 31 Mart 1339. \\ 051/5.43.3, 26 Agustos 1339/13 Muharrem 1342. \\ 051/7.63A, 6 Kanunuevvel 1337. \\ 051/7.63.5, 22 Kanunuevvel 1337. \\ 051/7.63.6, 5 Kanunusânî 1338/6 Cemaziyelevvel 1340. \\ 051/7.63.7, 10 Kanunusânî 1338/11 Cemaziyelāhir 1340. \\ 051/7.63.8, 13 Kanunusânî 1338/14 Cemaziyelevvel 1340 . \\ 051/7.63.11, 23 Kanunusânî 1338.
}

127. Bu konu hakkında bilgi için, Bk. Recai Doğan "Cumhuriyet'in Illk Yıllarında Tevhid-i Tedrisat Çerçevesinde Din Eğitim-Ögretimi ve Yapılan Tartışmalar", Cumhuriyet' in 75. Yılında Türkiye'de Din Eğitimi ve Ögretimi. Türk Yurdu Yay., Ankara 1999, s. 227-288. 
051/7.63.12, 24 Kanunusânî 1338 .

051/7.63.19, 19 Şubat 1338/20 Cemazeyalâhir 1340 .

051/7.63.24, 2 Mart 1338/2 Receb 1340.

051/7.63.26, 26 Mart 1338.

$051 / 7.63 .28$.

051/7.63.32, 15 Nisan 1338 .

051/7.63.35, 31 Mayıs 1338/4 Şevval 1340 .

051/7.63A5, 25 Haziran 1338.

051/7.64.1, 1 Ağustos 1338.

051/7.64.10, 16 Agustos 1338/21 Zilhicce 1340.

051/7.64.11, 16 Agustos 1338/21 Zilhicce 1340.

051/7.64.12, 18 Ağustos 1338 .

051/7.64.28, 5 Eylül 1338.

051/7.6430, 9 Eylül 1338.

051/7.6440, 4 Teşrinisânî 1338.

051/7.64 A3, 8 Teşrinisânî 1338.

051/7.64.46, 22 Teşrinisânî 1338.

051/7.64.53, 6 Kanunusânî 1339.

051/7.64.60, 20 Kanunusânî 1339/2 C. Ahir 1341 .

051/7.64.61, 24 Kanunusânî 1339.

051/7.64.62, 27 Kanunusânî 1339 .

051/7.64.71, 14 Mart 1339.

051/7.64.82, 26 Nisan 1339.

051/7.65.25, 17 Mart 1338/18 Receb 1340.

051/8.65.3, 24 Haziran 1339

051/8.65.9, 22 Zilkade 1341 .

051/8.65.33, 16 Teşrinivvel 1339.

051/8.65.43, 11 Kanunuvvel 1339.

051/8.65.44, 11 Kanunuvvel 1339.

051/8.65A5, 15 Kanunuvvel 1339.

051/8.65.46, 16 Kanunuvvel 1339.

051/13.113.6, 25 Kanunusânî 1338 .

051/13.113.15, 27 Şubat 1338.

051/13.113.20, 10 Mart 1338.

051/13.113, 22, 15 Mart 1338.

051/13.113.26, 5 Şubat 1338 .

051/13.11334, 1 Nisan 1338/21 Saban 1340.

051/13.113.55, 13 Eylül 1338.

051/13.113.70, 31 Kanunuevvel 1338.

\section{Süreli Yayınlar}

Ceride-i llmiye, 2. Sene, Aded 17, Zilkade 1333.

Ceride-i llmiye, 3. Sene, Aded 31, Cemaziyelevvel 1335.

Ceride-i Illmiye, 3. Sene, Aded 32, Şevval 1335.

Ceride-i Ilmiye, 3. Sene, Aded 33, Zilhicce 1335.

Hakimiyet-i Milliye, 4. Sene, No: 1070, 6 Şaban 1342/13 Mart 1340.

Takvim-i Vekâyî, No: 3034, 2 Muharrem $1336 / 19$ Teşrinievvel 1333.

TBMM Zabut Ceridesi, Devre II, İçtima Senesi II, c. 8/1, s. 827, 829, 17 Nisan 1340. 


\section{Kanun, Nizamname ve Talimatnameler}

Dârü'l Hilâfe Medreseleri Ders Cetvelleri ve Müfredat Programı: Ögüt Matbaası, Ankara, 30 Rebiülevvel 1342/10 Teşrinisâni 1339.

"Dâru'l-Hilâfetj'l-Aliyye Medâris Talimatnamesi": Medâris-i Illmiye Nizamnamesi, Şehzadebaşı Evkâf-ı İslamiye Matbaası, 1338-1341, s. 16-37.

"Dâru'l-Hilafeti'l-Aliyye Medresesi İle Taşra Medârisi Hakkında Nizamname": 4. T. Evvel 1333/16 Zilhicce 1335, Düstur IX, II. Tertib, Evkaf Matbaas1, Istanbul 1928, s. 745-752;

"Dârü'l-Hilafeti'l-Aliyye Mcdresesi ve Medresetü'l-Kuzât Nizamnamesi": Evkaf-1 Islamiye Matbaas1, 1340-1338.

"Islâh-1 Medâris Nizamnamesi": 18 Eylül 1330/10 Zilkade 1332, Düstur VI, II. Tertib, s. 1325-1330; Ilmiye Salnamesi, Matbaa-i Amire, Istanbul 1334, s. 657-660.

"Medâris-i İlmiyc Hakkında Kanun": 2 Nisan 1333/10 Cemaziyelâhire 1335, Düstûr IX, II. Tertib, Evkaf matbaası, İstanbul 1928, s. 598-600; Cerîde-i llmiye, 3. Sene, Aded 31, Cemaziyelevvel 1335, s. 877-880.

"Medâris-i İlmiye İmtihanları Hakkında Talimatname": Medâris-i llmiye Nizamnamesi, Şehzadebaşı Evkaf-1 Islamiye Matbaası, 1338-1341, s. 12-13.

"Medaris-i İlmiye Nizamnamesi Esbâb-1 Mûcibe Lâyihası": Medaris-i Ilmiye Nizamnamei, Evkaf-1 İslamiye Matbaası, 1341-1338, s. 3-5.

"Medaris-i İlmiye Nizamnamesi": 8 Mayıs $1337 / 30$ Şaban 1339, Düstur I, III. Tertib, s. 57-61; Evkaf-1 Islamiye Matbaası, 1341-1338, s. 6-11.

"Muallimîn ve Talebenin Askerlikten Tecilleri Hakkında Kanun": 21 Şubat 1337/13 Cemaziyelâhir 1339, Düstur I, III. Tertib, Milliyet Matbaası, İstanbul 1929, s. 219220.

"Muallimîn ve Talebenin Askerlikten Tecilleri Hakkındaki 21 Şubat 1337 Tarihli Kanuna Müzeyyel Kanun": 19 C. Ahir 1342/26 Kanunusânî 1340, Düstur V, III. Tertib, Necm-i İstikbal Matbaası, İstanbul 1931, s. 587-588.

"Mükellefiyet-i Askeriye Kanun-1 Muvakkatı": 16 Cemaziyelâhir 1332/29 Nisan 1330, Düstur VI, II. Tertib, Matbaa-i Amire 1334, s. 662-704

\section{Kitap, Tez ve Makaleler}

Bulut, Mehmet, Türkiye Büyük Millet Meclisi'nde Din Eğitimi Hizmetleri ve Dinî Yayın Konularında Yapilan Müzakereler Üzerine Bir Araştırma, Ankara Üniversitesi Sosyal Bilimler Enstitüsü, Basılmamı̧̧ Yüksek Lisans Tezi, Ankara 1991.

Çelik, Esma, Tevhid-i Tedrisat Kanununa Kadar Türkiye'de Medreseler, Ankara Üniversitesi Sosyal Bilimler Enstitüsü, Basılmamış Yüksek Lisans Tezi, Ankara 2000.

Doğan, Recai, "Cumhuriyet'in İlk Yıllarında Tevhid-i Tedrisat Çerçevesinde Din EğitimÖgretimi ve Yapılan Tartışmalar", Cumhuriyet'in 75. Yılında Türkiye'de Din Ë̆gitimi ve Ögretimi, Türk Yurdu Yay., Ankara 1999, s. 227-288.

Kütükoğlu, Mübahat, "Dâru’’ Hilâfeti'l Aliyye Medresesi ve Kuruluşu Arefesinde Istanbul Medreseleri", Islam Tetkikleri Enstituisü Dergisi, Sayı: 7/1-2'den ayrıbasım, Edebiyat Fak. Matbaası, Istanbul 1978.

Öztürk, Veli, Türkiye'de Din Eğitimi ve Siyaset (TBMM Zabullarında Din Eğitimi Tartışmaları 1920-1990), Basılmamış Doktora Tezi, Dokuzeylül Üniversitesi Sosyal Bilimler Enstitüsü, İzmir 1997.

Uzunçarşıllı, 1. Hakkı, Osmanlı Devletinin llmiye Teşkilatı, TTK Basımevi, Ankara 1988. 
Yazıcı, Nesimi, "Osmanlıların Son Döneminde Din Görevlisi Yetiştirme Çabaları Üzerine Bazı Gözlemler", Diyanet Dergisi XXVII, Sayı : 4, Ankara 1991, s. 55-123.

Yazıcı, Nesimi, "Kayseri Medaris-i llmiyye Karar Defteri Üzerine Bazı Düşünceler", II. Kayseri ve Yöresi Tarih Sempozyumu Bildirileri, Kayseri 1998, s. 461-469.

Zengin, Zeki Salih, Tanzimat Dönemi Osmanlı Örgün Eğitim Kurumlarında Din Eğitimi ve Ö̆rretimi (1839-1876), Basılmamış Doktora Tezi, Erciyes Üniversitesi Sosyal Bilimler Enstitüsü, Kayscri 1997.

Zengin, Zeki Salih, II. Meşrûtiyet Döneminde Medreselerin Islahı Hareketleri ve Din Eğitimi (1908-1918), Erciyes Üniversitesi Sosyal Bilimler Enstitüsü Basılmamış Yüksek Lisans Tezi, Kayseri 1993. 